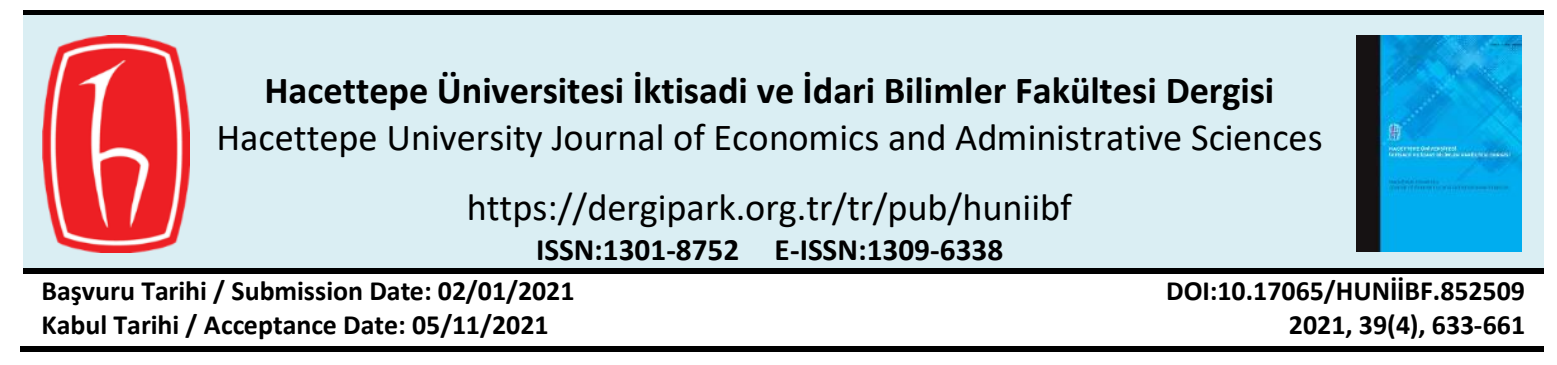

Araştırma Makalesi / Research Article

\title{
The Impact of Syrian Conflict and the Refugee Crisis on Labour Market Outcomes of Host Countries
}

Eleftherios Giovanis ${ }^{1}$, Öznur Özdamar²

\begin{abstract}
The civil war in Syria, which started in March of 2011, has led to a massive influx of forced migration, especially from Northern Syria to the neighbouring countries. The unexpected movement of refugees has created large exogenous labour supply shocks with potentially significant effects on the labour and living standard outcomes of natives in the host countries. Using a difference-indifferences (DID) framework, this study explores the impact of Syrian refugees on labour market outcomes in Jordan and Turkey. Furthermore, we implement an instrumental variables (IV) approach within the DID framework. The results are mixed and vary, not only across the labour outcomes explored but also across demographic and socio-economic groups, as females and low educated are mainly affected by the refugee crisis negatively. Main policy implications include the design and implementation of active labour market policies, necessary measures to address the employment in the formal sector, encouraging the private sector to employ Syrian refugees in sectors where migrant workers would like to work and natives are not willing to work. Other policies include the implementation of realistic scenarios to integrate the refugees in the domestic labour market that will be beneficial for the domestic economy. Furthermore, national governments and authorities should maximize the job creation potential by collaborating with international actors. School enrollment for refugees' children and granting formal work permits to their parents are other policies that may affect natives and refugees positively.
\end{abstract}

Keywords: Difference-in-differences, forced migration, instrumental variables, Syrian refugees, wages, unemployment.

\section{Suriye'deki Çatışmalar ve Mülteci Krizinin Ev Sahibi Ülkelerin İşgücü Piyasası Göstergeleri Üzerine Etkisi}

Öz

2011 yılı Mart ayında başlayan Suriye iç savaşı, özellikle Suriye'nin kuzeyinden komşu ülkelere doğru zorunlu bir göç akınının yaşanmasına neden olmuştur. Bu beklenmeyen göç hareketi, göç edilen ev sahibi ülkelerin vatandaşlarının yaşam standardı ve işgücü piyasası göstergeleri üzerinde etkiler bırakan dışsal işgücü arz şokları yaratmıştır. Bu çalışma Farkların-Farkı (FF) yöntemini kullanarak Suriyeli mültecilerin Türkiye ve Ürdün'de işgücü piyasası göstergeleri üzerine etkisini incelemektedir. Illave olarak, araç değişkeni (AD) yaklaşımı FF yöntemi içerisine dahil edilerek uygulanmıştır. Sonuçlar incelenen her bir işgücü piyasası göstergesi açısından değişmekte olup, demografik ve sosyo-ekonomik gruplar açısından da farklılaşmaktadır. Örneğin kadınlar ve az eğitimli bireyler mülteci krizinin negatif etkiler yarattığı gruplardır. Aktif işgücü politikalarının tasarım ve uygulanması, kayıtı istihdamın sağlanması noktasında gerekli önlemlerin alınması, ülke vatandaşlarının çalışmayı tercih etmediği ama göçmenlerin çalışmak istediği özel sektör kollarında Suriyeli mültecilerin çalışması başlıca politika uygulamaları arasında sayılabilir. Bir diğer politika önerisi ülke ekonomisine fayda sağlayacak şekilde işgücü piyasasındaki göçmenlerin entegrasyonuna yönelik gerçekçi uygulamaların geliştirilmesidir. Göç alan ülke hükümetlerinin uluslararası aktörlerle iş birliği halinde istihdam yaratma potansiyellerini artırmaları da önemlidir. Göç alan ülke vatandaşları ve mültecileri pozitif yönde etkileyen bir diğer politika önerisi mülteci çocukların formel eğitim almaları ve ebeveynlerine kanuni çalışma izinlerinin sağlanmasıdır.

Anahtar Kelimeler: Farkların farkı yöntemi, zorunlu göç, araç değişkenleri, Suriyeli mülteciler, ücretler, işsizlik.

\footnotetext{
${ }^{1}$ Sorumlu Yazar (Corresponding Author), Associate Professor, Izmir Bakircay University, Faculty of Economics and Administrative Sciences, Department of International Trade and Business, eleftherios.giovanis@bakircay.edu.tr, https://orcid.org/0000-0002-7492-7461

2 Associate Professor, Izmir Bakircay University, Faculty of Economics and Administrative Sciences, Department of Economics, oznur.ozdamar@bakircay.edu.tr, https://orcid.org/0000-0002-2188-3733
} 


\section{INTRODUCTION}

Forced migration and refugees pose political, moral, socio-cultural and economic challenges for the host countries. According to the United Nations High Commissioner for Refugees-UNHCR (2019), the scale of this challenge is larger than ever, with almost 79.5 million people forcibly displaced worldwide by conflicts. The civil war in Syria has produced more refugees than any other conflict in the past two decades. By the end of 2019, almost 5.3 million refugees were coming from Syria in Turkey, Lebanon, Jordan, Iraq and Egypt only, with around 3.5 million located in Turkey; about 914,000 in Lebanon followed by Egypt, Jordan and Iraq ranging between 130 and 660 thousand. $^{1}$

The main objective of this study is to explore the impact of the Syrian refugee influx on labour outcomes in Jordan and Turkey. Moreover, we explore the effect of the Syrian refugees on the labour outcomes of both natives and migrants in Jordan and Turkey. The motivation for exploring the impact on migrants' well-being outcomes lies in earlier studies that mainly focus on natives ${ }^{2}$. The analysis will also take place across gender, age and education groups. We will investigate and compare the impact of the Syrian refugee crisis on wages and job security across those employed in the formal and informal sector and those occupied in high and low-skilled jobs. The aim is to explore whether natives and migrants are displaced in the formal or informal sector by the refugees and whether they are displaced mainly in lowskilled or high-skilled jobs. We assume that refugees can be either substitute for one group of workers but a complement to another group. Therefore, we explore the impact of the refugee crisis on natives and migrants by their education level and job skills. The results vary between countries and across the labour outcomes explored, and across various demographic and socio-economic groups.

The remaining sections are organised as follows: Section 2 discusses the earlier literature on the impact of the refugee inflows on labour outcomes. In section 3 we present the methodology applied and we describe the data employed in the empirical work. We report the main findings in section 4 , and in section 5 , we discuss the main concluding remarks and policy implications of the migration effect.

\section{LITERATURE REVIEW}

Several studies have explored the impact of refugees on the labour outcomes of native populations. The most similar studies to our paper are by Del Carpio and Wagner (2015), Tumen (2018), and Fallah et al. (2019). Del Carpio and Wagner (2015), using the Turkish Household Labour Force Survey (HLFS), implemented a similar identification strategy to explore the impact on employment. The study suggests that Syrian forced migration had a large-scale displacement in the informal sector for native people. On the contrary, formal employment of natives noted a significant increase. In particular, for every ten refugees, almost seven Turkish workers are displaced in the informal sector, while for the same number of refugees, around four jobs in the formal sector for the natives are created. Ceritoglu et al. (2017) found a negative impact of the Syrian migrant influx on labour outcomes of natives in Turkey, such as rising unemployment and a decline in labour force participation. Fallah et al. (2019) explored the impact of Syrian refugees on labour outcomes in Jordan employing a DID technique. To further elucidate the endogeneity coming from the "sorting" process, which characterizes the refugees' decision to relocate in certain areas, the authors use an instrumental variables approach. The instrument for the locality share of refugees is based on the distance to the locality from the Zaatari refugee camp; Jordan's largest camp. Overall, the study shows no deterioration in the natives' labour outcomes.

These findings are supported by studies using similar identification strategies, such as the DID comparing areas with a low and high number of refugees and investigating the impact of forced migration in other regions and countries of the world. For instance, Kreibaum (2016) explored the effect of Congolese refugees on natives in Uganda and found that refugee inflows increase educational attainment, employment opportunities and household welfare, measured by the household expenditures. However, natives are less likely to use health facilities due to congestion caused by the increasing number of refugee inflows. Furthermore, some vulnerable groups, such as low skilled workers, are displaced in terms of employment, directly forced into competition with the refugees, indicating that refugees are substitutes 
to those natives in the production process. Borjas and Monras (2017) explored the impact of the exogenous labour supply shocks created by four refugee crises on native populations. In particular, they explore the Balkan refugees following the Yugoslav wars between 1991-2001; the Algerian refugees resulted from the Algerian independence war in 1962; the Soviet refugees in Israel in 1990 and the "Marielitos" who fled from the port of Mariel in Cuba in 1980 and the destination was Miami. Using a DID framework, they found a negative impact on the low-skilled workers in the Algerian refugees in France and the Marielitos in Miami, while they obtained a negative effect on wages and employment in the highskilled Israelis competing with large numbers of high-skill Soviet migrants.

A number of qualitative studies have also explored the impact of the Syrian migration flows on the labour outcomes and the economies of the host societies. For instance, Duruel (2017) using field studies, observations, interviews and comparative statistics, found that the influx of refugees does not have a significant negative impact on formal employment. However, the study found adverse effects on informal employment and wages. The findings show that Syrian refugees increase the total demand in the affected areas- with high refugee density- resulting in a drop in labour costs that leads to an increase in employment in the formal sector. Also, the study shows that those who lose their informal jobs are either unemployed or out of the workforce. While unemployment rates and formal employment increased slightly, labour force participation, informal employment, and employment rates slightly decreased. Women, young people and those with low education levels referred to as disadvantaged groups in the labour market felt the effect more.

In another study, Bahçekapılı and Çetin (2015) have estimated the differences in average rates in the years preceding and following the influx of Syrian refugees, and present a descriptive analysis of the impact of Syrians on unemployment rates, inflation, foreign trade, and internal migration. According to those, Syrian refugees have increased unemployment and reduced prices in provinces most affected by the Syrian influx crisis. Işcan and Çakir (2019) have examined the impact of migration on Syrians' labour outcomes. The authors developed a field study by conducting a survey and collecting data of over 2,500 refugees and asylum seekers in 26 provinces between March and July of 2017. The majority of the asylum seekers and refugees surveyed do not work in a regular and permanent job at 82.7 percent. 75.5 percent replied that they either do not work or work under a daily wage contract in the informal sector. 50.5 percent work in temporary jobs in the private sector.

Özkarsli (2015) has examined the impact of migration on Syrian refugees' labour outcomes in the province of Mardin in Turkey. The author found that this province is an attractive place for Syrian refugees given the demand and need in certain job positions in the construction and agricultural sector, as well as in housekeeping and childcare for women. Because of the large number of migrant workers and Jordan's policy heritage and recollections of Palestinian and Iraqi refugees, the employment of Syrian refugees in Jordan is a complex economic and political issue (Lenner, 2016). Prior to the Syrian conflict, Jordanians had an unemployment rate of over 14 percent, which grew to 15.8 percent in 2016. (Al Sharif, 2017). Female and youth unemployment (15-25 years) were particularly high, with both categories reporting jobless rates of approximately 30 percent (Stave and Hillesund, 2015).

This study attempts to contribute to the earlier literature in two ways. First, there is no study investigating the impact of Syrian refugees on both natives' and migrants' labour outcomes in Jordan and Turkey. Second, we expand our analysis by decomposing and investigating the effect of the Syrian refugee crisis on labour outcomes across gender, age and education groups and across formal and informal sector employment and high versus low skilled jobs.

\section{METHODOLOGY AND DATA}

\subsection{Difference-in-Differences (DID) Framework}

The empirical set-up for our analysis is based on a DID framework. More specifically, following the studies by Del Carpio and Wagner (2015) and Tumen (2018) we estimate the following DID model: 


$$
E_{\text {irt }}=a_{0}+a_{1} T_{\text {ir }}+a_{2} P_{i t}+a_{3}\left(T_{\text {ir }} \times P_{i t}\right)+a^{\prime} \mathbf{X}_{\text {irt }}+l_{r}+\theta_{t}+\varepsilon_{\text {irt }}
$$

Where $E_{\text {irt }}$ is the outcome of main interest for individual $i$, in region-governorate $r$ and year $t . T_{i r}$ takes a value of 1 for the treated group and 0 for the control, while $P_{i t}$ takes a value of 1 for the year 2012 and after, where the Syrian refugee influx started taking place and 0 for the years before 2012 . We should notice that while the civil war started in 2011, the inflows mainly began in 2012, especially in Turkey (Cagaptay and Menekse, 2014). Furthermore, we prefer to consider the impact of the refugee crisis by considering one-year lagged inflows, since the surveys take place in the spring of each year. We explore five labour outcomes: real wages; employment in the formal sector; unemployment; labour force participation; the contract type, and in particular, permanent versus a temporary job. Real wages are adjusted for inflation using 2012 as the base year. The remaining four labour outcomes are dummy variables. In particular, the employment variables takes a value of 1 if the respondent is employed and 0 if is unemployed. For formal employment, we define the value of 1 if the worker is employed in the formal sector and 0 if is employed in the informal sector. Labour market participation takes a value of 1 if the respondent participates in the labour market and 0 otherwise. Finally, for the contract type, the variable takes a value of 1 whether the respondent is employed under a permanent contract and 0 if is employed in a temporary job. The interaction term of $T_{i r}$ and $P_{i t}$ and the estimated coefficient $a_{3}$ is the DID estimator, which gives the causal effect of the main interest.

Vector $\mathbf{X}_{\text {irt }}$ is a vector of individual and household characteristics. The control variables for Jordan include gender, age, education level, marital status, household size, and parental characteristics, such as education and employment status. Furthermore, in the case of labour outcomes, except for unemployment, we include the firm size, the professional class according to the International Standard Classification of Occupations (ISCO88) and the industry code. For Turkey, we use the same controls except for the parental characteristics because these are not recorded in the HLFS. Sets $I_{r}$ and $\vartheta_{t}$ are respectively the region-governorate and year fixed effects.

The next step for the identification strategy discussed so far is to present the "treated" and "control" groups. In particular, in figures 1-2 and table 1 we illustrate the treated-control areas in the countries we explore. According to table 1, figure 1 and the reports by UNHCR ${ }^{3}$, the governorates of Amman, Zarqa, Balqa, Irbid, and Mafraq will form the treated group in Jordan The remaining governorates presented in table 1 and illustrated in figure 1 will comprise the control group. 
Table 1: Treated and Control Areas-Governorates

Panel A: Jordan

Treated

Cairo

Alexandria

Damietta

Sharkia

Kalyoubia

Giza

\section{Treated}

Amman

Zarqa

Balqa

Irbid

Mafraq
Panel B: Turkey

\section{Control}

Treated

Control

Madaba

TRC1

TRA1

Jarash

TRC2

TRA2

Ajloun

TRC3

TRB1

Karak

TRB2

Tafileh

Ma'an

Aqaba

Figure 1: The proportion of Syrian Households by Governorate in Jordan, 2015

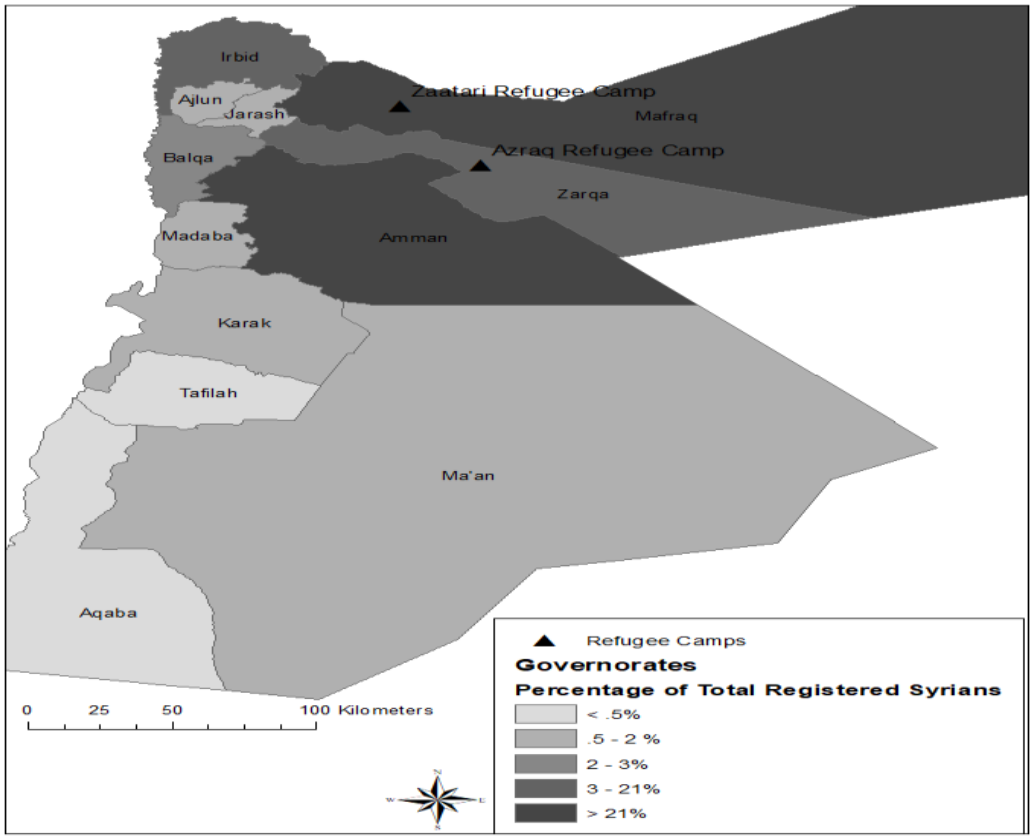

Source: Salemi et al., (2018).

In table 1 and figure 2 we present the treated-control groups for Turkey mapped at the Nomenclature of Territorial Units for Statistics (NUTS) 2 level. The control area corresponds to Eastern Anatolia, which is specified and defined as the Northeast Anatolia (Kuzey Doğu Anadolu) coded as TRA and the Middle East Anatolia (Orta Doğu Anadolu) coded as TRB. The treated group corresponds to the southeastern Anatolia NUTS 1 level (Güney Doğu Anadolu) coded as TRC. We should notice that we will exclude the provinces of Adana and Hatay from our analysis, even though they have received a significant number of Syrian refugees illustrated in the dark grey shaded areas in figure 2 . The principal justification 
for doing this is that these provinces belong to the Mediterranean region that includes Mersin and Antalya, two large provinces having received a trivial number of refugees from Syria. Their inclusion, in this case, would most likely pose a threat to our identification. Furthermore, these provinces present substantial differences in terms of both economic, demographic and socio-cultural characteristics.

Figure 2: Identification Strategy in Turkey based on NUTS-2 Level

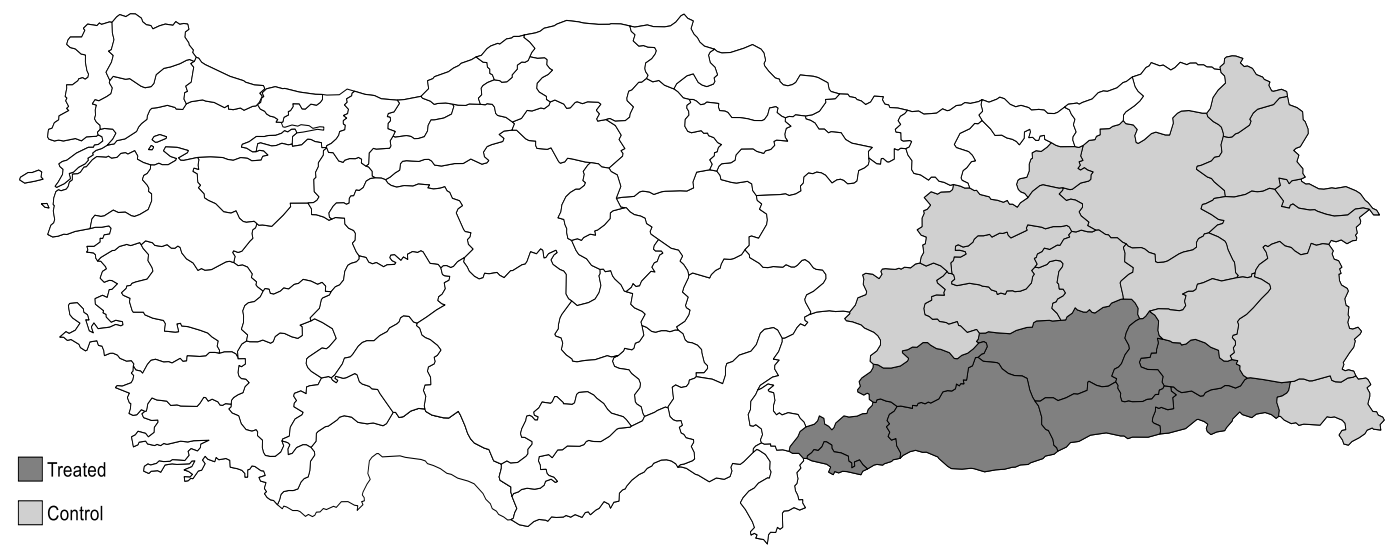

The reasoning behind the difference-in-difference (DID) approach was utilized by John Snow as early as the 1850s (Snow, 1855, 1856). Relevant literature has employed DID through time, and similar frameworks have been applied. Simon (1966) conducted one of the earliest researches investigating the impact of price elasticity of liquor sales. The goal was to compare "before" and "after" sales in a certain state that had seen a price change to places that had not experienced a price change.

DID is a quasi-experimental design, and it relies on cross-sectional or longitudinal data from treatment and control groups to estimate a causal effect using an appropriate counterfactual. DID is used to estimate the effect of a specific intervention or treatment such as the enactment of a policy, the implementation of a large-scale programme or the large scale Syrian influx in our case. Then it compares the changes in outcomes over time between a population enrolled in a programme or being affected by a policy, intervention or shock, such as migration (the treated or intervention group) and a population that is not affected (the untreated or control group).

DID is commonly employed in observational data, such as the surveys utilized in this study. It requires data from a cohort or panel that includes pre-and post-intervention periods, such as individualhousehold or company level data throughout time, or repeated cross-sectional data. The DID framework eliminates any biases in post-intervention comparisons between the treated and control groups caused by permanent differences, as well as biases in the treatment group caused by changes in trends caused by other determinants of the outcome.

We start with a simple setup using the case in this study to show the main idea of DID. The treatment variable is denoted by $\mathrm{T}$. It is a binary variable with $t \in\{0,1\}$, taking a value of 1 for the treated group, as it can be seen in table 1 , and 0 for the control subjects-groups. For instance, the control groups in this study comprise the governorates of Madaba, Jarash, Ajloun, Karak, Tafileh, Ma'an and Aqaba in Jordan and the regions of TRA and TRB in Turkey. The time-period dummy variable is $P, p \in\{0,1\}$, and the value of 1 indicates the period after the treatment (post-intervention), and 0 denotes the period before the treatment (pre-intervention). 
Figure 3: Graphical Explanation for the DID Estimation

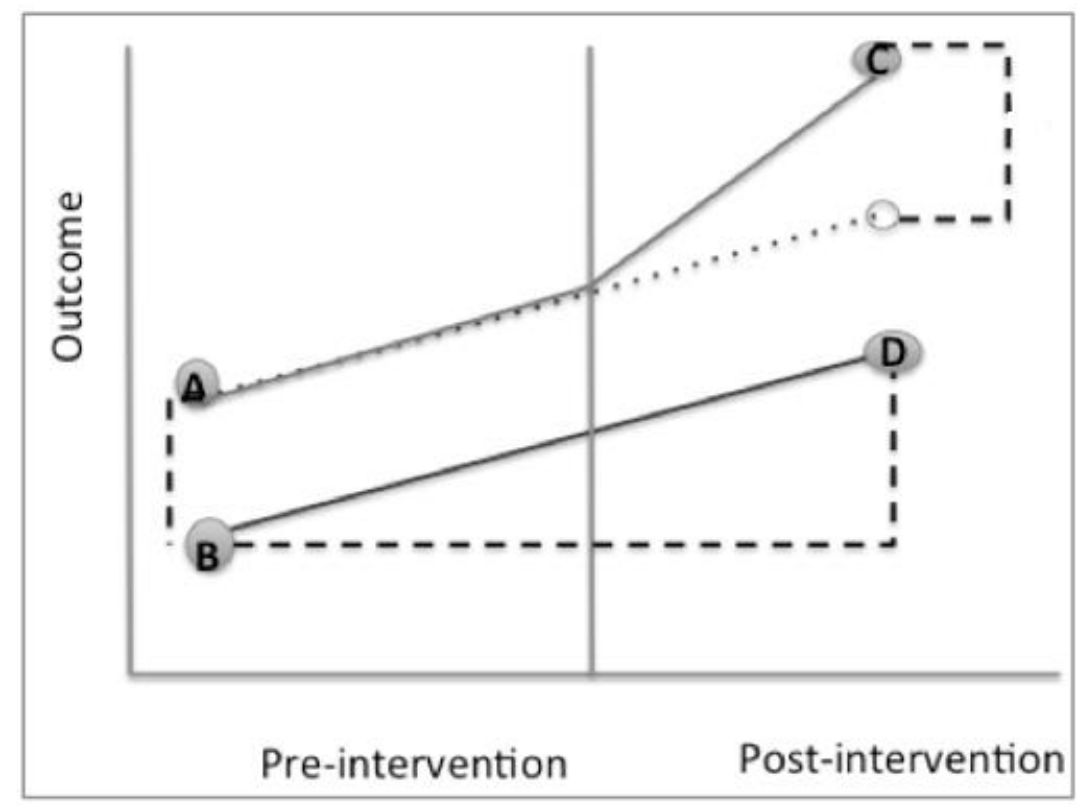

Source: https://www.publichealth.columbia.edu/research/population-health-methods/differencedifference-estimation.

We depict the DID framework in figure 3 and table 2 . The baseline averages for the treatment and control groups are represented by points $A$ and $B$, respectively, which depict the difference between the two groups before the intervention or policy implementation. The vertical line in the graph illustrates the intervention time, while D-B shows the temporal trend of the control group. The DID estimator is obtained from the difference of (C-A)-(D-B). Thus, C-A represents the difference in treatment between the postintervention and pre-intervention groups and DID estimator is the difference between this term and the time trend of the control. Without treatment, the treated group's trend would be the same as the control group's, and it would continue to be parallel even after the intervention, which is the post-intervention period.

This parallel trend assumption shows that differences in expected potential untreated outcomes over time-dependent on $\mathbf{X}$ variables are unrelated to whether one is in the treated or control group in the post-treatment period. This is a critical assumption of the DID methodology, which states that if the treated had not been given the treatment, both $T=1$ and $T=0$ sub-populations would have had the same temporal trends conditional on variables X. Because the non-treatment potential outcomes for the treated and control groups have the same trend, any deviation in the trend of the treated group's observed outcomes from the trend of the control's observed outcomes will be directly attributed to the effect of the treatment and not to differences in other characteristics of the treated and control groups. For this reason, we will test the parallel trend assumption (Angrist and Pischke, 2008; Autor, 2003). 
Table 2: Explanation of the DID Estimation

\begin{tabular}{cc}
\hline Calculation & Interpretation \\
B & Baseline average \\
D-B & Time trend in the control group \\
A-B & Difference between two groups pre-intervention \\
(C-A)-(D-B) & The difference in changes over time \\
\hline
\end{tabular}

\subsection{Instrumental Variables (IV)}

The second specification model is to take the logarithm of the population of Syrian refugees in the host areas-governorates and employ an IV approach within the DID framework using the two-step optimal Generalized Method of Moments (GMM) estimator. The instrument is similar to earlier studies (Del Carpio and Wagner, 2015; Tumen, 2018) based on the distance from the source governorates in Syria to destination provinces in Turkey. In Jordan, we will additionally use the distance between the refugee camps and the respondent's governorate. The single instrument used is:

$$
I V 1_{r t}=\sum_{s} \frac{1}{D_{s r}} P_{s} R_{t}
$$

In instrument (2), $D_{s r}$ is the shortest travel distance from a Syrian governorate $s$ to each areagovernorate $r$ in the countries we explore. We apply the Haversine formula instead of the Euclidean distance, as the first accounts for the great-circle distance along the surface of the Earth (Sinnott,1984). In relation (2), we get the inverse distance weighting that gives more weight to closer points. However, for Jordan, we also include the distance between the refugee camps and the centroid of the Jordanian governorates. We consider the governorates in Jordan and the areas at NUTS 2 level for Turkey in table 1. For example, in Turkey and the NUTS-2 level, we have 7 areas and 13 Syrian governorates, which implies 91 pairs (7×13). Similarly, for Jordan, we have 195 pairs that includes also three refugee camps; the Zaatari, Mrajeeb Al Fhood and Azraq. Syrian refugees in Jordan originate mainly from Damascus and its rural suburbs, followed by those coming from the governorates of Aleppo, Homs and Daraa. On the other hand, Turkey has hosted almost 90 percent of Syrian refugees coming from Aleppo, Al-Raqqah, Hamah, Lattakia, Idlib, Al-Hassakeh located in the borders with Turkey. Nevertheless, we will take the distance and population statistics of all 13 governorates of Syria. Hence, $P_{s}$ in relation (2) denotes the population of each Syrian governorate in $\mathbf{2 0 1 0}$ before the civil war, and $R_{t}$ is the proportion of the Syrian refugees over the total population in the host country corresponding to one year before the interview. As we show in table 3, there have been very few Syrians before 2012, both regular migrants and refugees, across the countries we explore. Hence, this measure captures the variation in the cross-locality in the share of Syrian refugees and migrants, possibly due to the Syrian civil war of 2011. Peri (2012) and Black et al. (2015) used this instrument to explore voluntary migration, while Baez (2011) and Ruiz and Vargas-Silva (2015) have employed this instrument to examine the impact of 500,000 refugee inflows resulting from the genocides of Burundi and Rwanda and fled in Kagera- a region in northwestern Tanzania. Following the discussion so far, estimate the following regression using the two-step optimal GMM method:

$$
E_{\text {irt }}=b_{0}+b_{1} \operatorname{lnR} P_{r t}+b^{\prime} \mathbf{X}_{i r t}+l_{r}+\theta_{t}+\varepsilon_{i r t}
$$

Where the variables and vector $\mathbf{X}$ are defined as in (1), while $\ln R P_{r t}$ denotes the logarithm of the Syrian migrant population instrumented with the single variable (2). In both regressions (1) and (3), standard errors are clustered at the regional-governorate level combined with wild bootstrapping. As we have mentioned we use a single instrument and for the endogeneity, we use the Wooldridge robust score (Wooldridge, 1995) that follows the chi-square distribution with one degree of freedom. 


\subsection{Threats to the Identification Strategy}

A major threat to our identification strategy is that the Syrian refugees tend to migrate into areas with a large concentration of Syrian migrant enclaves and diaspora. Earlier studies have used the past values of migration flows, arguing that historical settlement patterns of immigrants may drive the migrants' location decisions (Bartel, 1989; Altonji and Card, 1991). Hence, migrants tend to migrate into areas with a strong diaspora presence, where previous generations or migrant flows have built immigrant enclaves, sharing common cultural and social characteristics (Bartel, 1989; Beine et al., 2011). These diasporas may also reduce assimilation and information costs for the migrants, providing support on housing, employment, and adjusting to cultural issues and social norms (Beine et al., 2011). However, as we show in table 3, the number of refugees and regular migrants from Syria before the civil war is significantly lower compared to the numbers that have reached following the refugee crisis. We present the total number of refugees and regular Syrian migrants, to highlight that even though the Syrian refugees may tend to locate in areas with large established Syrian enclaves, the low number of regular migrants before the crisis does not pose a particular threat to our estimates. Furthermore, until 20132014 Syrian refugees were mainly located in camps in Turkey (Esen and Binatll, 2017). Moreover, the highest number of Syrian migrants before the refugee crisis and a large movement of Syrian refugees took place in Istanbul, not included in the analysis, like other major metropolitan areas-cities, including Izmir and Bursa.

However, one of the main objectives of this study is to explore the impact of the Syrian refugee influx on the labour outcomes of both natives and migrants. Unfortunately, the survey used in the empirical analysis for Turkey records the required information to identify whether the respondent only in 2009-2013. Thus, investigating the impact of Syrian refugees over the years beyond 2013 will create incomparable results. As a further result, we would not be able to decompose the effect of Syrian migration inflows on the labour outcomes of natives and migrants. Furthermore, even though there is a degree of dispersion of Syrian migrant across Turkey, the share of Syrian refugees in the regions we include in the analysis remain relatively high and the same, while the percentages of Syrians in other provinces are very low. ${ }^{4}$

Table 3: Averages of Syrian Refugees and Regular Migrants

\begin{tabular}{cl}
\hline Jordan & \\
2010 & 38,130 \\
2016 & $1,265,514$ \\
Turkey & \\
$2008-2011$ & 9,500 \\
$2012-2015$ & $2,816,156$ \\
\hline
\end{tabular}

Source: United Nations High Commissioner for Refugees (UNHCR), Department of Statistics (Jordan) http://www.dos.gov.jo/dos home e/main/population/census2004/index.htm, and the Directorate General of Migration Management (DGMM) and UNHCR for Turkey.

Similarly, another key threat to the validity of the instrument employed in the analysis is that areas located close to a border, as in the case of Turkey, or close to the refugee camps, may systematically differ from those that are further away. While we could control for the physical distance only, our instrument incorporates multiple border-crossings between Syria and Turkey and multiple origins-destinations in the case of Jordan, including also the refugee camps. Thus, refugees from Syrian governorates will use also different border crossings to reach various parts of the host countries, allowing us to directly control the distance from the borders. In particular, in Jordan, there are two main border crossings in Dar'a/Ramtha 
and Naseeb/Jaber and many other unofficial crossings. In Turkey, there were eight border crossings. However, after 2013, five of them were closed ${ }^{5}$.

Another possible drawback in our estimates is that Turkey signed an agreement with the European Union in 2016 on the exchange of refugees. Thus, migrants may choose Turkey as a transit country to Europe using the Balkan or the Aegean route. However, our empirical analysis for Turkey relies on data derived up to 2013. Furthermore, the evidence shows that refugees also use Jordan and Egypt as transit countries to Europe using the Mediterranean route (Brian and Laczko, 2016; Baklacioğlu, 2017).

\subsection{Data}

For the empirical analysis, we derived the data from various surveys. In particular, we used the Integrated Labor Market Panel Surveys (ILMPS) for Jordan in 2010 and 2016. For Turkey, we used the cross-sectional Household Labour Force Survey (HLFS) in 2009-2013. The ILMPS is provided by the ERF NADA data portal (OAMDI, 2019), while the Turkish Statistical Institute (TURKSTAT) has provided the HLFS in Turkey. The population of Syrian governorates is available at the Central Bureau of Statistics (http://cbssyr.sy/). We derived the statistics of Syrian migration in Jordan from the United Nations High Commissioner for Refugees (UNHCR), the Jordan Population and Housing Census from the Department of Statistics. For Turkey, the data are available at the Directorate General of Migration Management (DGMM https://en.goc.gov.tr/).

\section{EMPIRICAL RESULTS}

\subsection{Jordan}

In table 4 we report the results for the DID and DID-IV GMM estimators for natives and migrants in Jordan. Regarding natives, the results are mixed. We find a positive impact on employment and formal employment for both natives and migrants in Jordan though, we found an adverse effect on the labour force participation and the probability of being employed in a permanent position. Furthermore, the refugee crisis affects adversely the migrants' wages. Our results are partly consistent with previous studies that found no impact of the Syrian migration on labour outcomes, such as employment and wages (Fakih and Ibrahim, 2016; Fallah et al., 2019). Fallah et al. (2019) found that the impact of Syrian migration had no effect on unemployment but a positive impact on formal employment for Jordanians, suggesting that there was a shift in the type of jobs Jordanians do, rather than a loss in employment or job creation. Nevertheless, our results show also a positive impact of the Syrian refugees on employment opportunities.

However, these studies have not explored the impact on the permanent contract, where we found a negative, but a small impact of 0.8 and 1.36 percent respectively for the natives and migrants. On the contrary, while Fallah et al. (2019) found an insignificant impact on monthly wages, our findings show a significant and negative effect for migrants. Thus, our results show that Syrian migration does not displace Jordanian workers in terms of unemployment, and increases the probability of being employed in the formal sector. However, Jordanian workers are less likely to participate in the labour market and more likely to work in temporary job positions. Regarding migrants, we also find a negative impact of the Syrian refugee crisis on their earning potential in terms of monthly wages. 
Table 4: DID and DID-IV Estimates for Natives and Migrants in Jordan

\begin{tabular}{|c|c|c|c|c|}
\hline \multirow[t]{2}{*}{ DID } & \multicolumn{2}{|c|}{ DV: Formal Employment } & \multicolumn{2}{|c|}{ DV: Unemployment } \\
\hline & Natives & Migrants & Natives & Migrants \\
\hline \multirow[t]{2}{*}{ Treat $\left(a_{1}\right)$} & -0.0202 & $-0.0527 * * *$ & $-0.0260 * *$ & -0.0053 \\
\hline & $(0.0188)$ & $(0.0161)$ & $(0.0110)$ & $(0.0201)$ \\
\hline \multirow[t]{2}{*}{ Post $\left(a_{2}\right)$} & $-0.0348^{*}$ & $-0.0582 * * *$ & $0.0417^{* * *}$ & $0.0509 * *$ \\
\hline & $(0.0186)$ & $(0.0178)$ & $(0.0114)$ & $(0.0213)$ \\
\hline \multirow[t]{2}{*}{ Treat*Post $\left(a_{3}\right)$} & $0.0312^{*}$ & $0.0268 * * *$ & $-0.0252^{* *}$ & 0.0124 \\
\hline & $(0.0167)$ & $(0.0212)$ & $(0.0124)$ & $(0.0109)$ \\
\hline No. Observations & 10,748 & 987 & 30,834 & 3,364 \\
\hline R-square & 0.8065 & 0.8738 & 0.0581 & 0.0643 \\
\hline \multirow[t]{2}{*}{ DID-IV } & \multicolumn{2}{|c|}{ DV: Formal Employment } & \multicolumn{2}{|c|}{ DV: Unemployment } \\
\hline & Natives & Migrants & Natives & Migrants \\
\hline The logarithm of Syrian Migrant & $0.0032^{*}$ & $0.0168 * * *$ & $-0.0042 * *$ & $-0.0048^{*}$ \\
\hline Population & $(0.0017)$ & $(0.0047)$ & $(0.0021)$ & $(0.0026)$ \\
\hline No. Observations & 10,748 & 987 & 30,834 & 3,364 \\
\hline Centered R-square & 0.8081 & 0.8917 & 0.0633 & 0.0801 \\
\hline Weak Identification Test: Cragg-Donald & $7,900.113$ & $2,507.354$ & $9,838.172$ & $4,492.472$ \\
\hline Wald F statistic & {$[0.000]$} & {$[0.000]$} & {$[0.000]$} & {$[0.000]$} \\
\hline Wooldridge Robust Score Chi-Square Test & 0.5536 & 0.0514 & 0.1615 & 0.0120 \\
\hline for Endogeneity & [0.4568] & [0.8206] & [0.6877] & {$[0.9126]$} \\
\hline \multirow[t]{2}{*}{ DID } & \multicolumn{2}{|c|}{ DV: Permanent Contract } & \multicolumn{2}{|c|}{ DV: Labour Force Participation } \\
\hline & Natives & Migrants & Natives & Migrants \\
\hline \multirow[t]{2}{*}{ Treat $\left(a_{1}\right)$} & $0.0753^{* * *}$ & $0.1076 * * *$ & -0.0286 & 0.0515 \\
\hline & $(0.0303)$ & $(0.0340)$ & $(0.0197)$ & $(0.0391)$ \\
\hline \multirow[t]{2}{*}{ Post $\left(a_{2}\right)$} & $-0.0724 *$ & $-0.1031 * * *$ & $-0.0452 * *$ & -0.0198 \\
\hline & $(0.0427)$ & $(0.0365)$ & $(0.0181)$ & $(0.0213)$ \\
\hline \multirow[t]{2}{*}{ Treat*Post $\left(a_{3}\right)$} & $-0.0697 *$ & $-0.1014^{*}$ & $-0.0072 * *$ & $-0.1464 * * *$ \\
\hline & $(0.0404)$ & $(0.0599)$ & $(0.0034)$ & $(0.0257)$ \\
\hline No. Observations & 10,755 & 987 & 32,622 & 3,730 \\
\hline R-square & 0.3707 & 0.4448 & 0.3648 & 0.4091 \\
\hline \multirow[t]{2}{*}{ DID-IV } & \multicolumn{2}{|c|}{ DV: Permanent Contract } & \multicolumn{2}{|c|}{ DV: Labour Force Participation } \\
\hline & Natives & Migrants & Natives & Migrants \\
\hline The logarithm of Syrian Migrant & $-0.0078 * *$ & $-0.0136^{*}$ & $-0.0080 * * *$ & $-0.0207^{*}$ \\
\hline Population & $(0.0036)$ & $(0.0077)$ & $(0.0021)$ & $(0.0108)$ \\
\hline No. Observations & 10,755 & 987 & 32,622 & 3,730 \\
\hline Centered R-square & 0.3723 & 0.5696 & 0.3668 & 0.4123 \\
\hline Weak Identification Test: Cragg-Donald & $7,910.127$ & $1,285.450$ & $29,941.32$ & $5,018.691$ \\
\hline Wald F statistic & {$[0.000]$} & {$[0.000]$} & {$[0.000]$} & {$[0.000]$} \\
\hline Wooldridge Robust Score Chi-Square Test & 1.0873 & 0.0889 & 2.0023 & 1.3307 \\
\hline for Endogeneity & [0.2968] & {$[0.7646]$} & [0.1571] & {$[0.2487]$} \\
\hline DV: Logarith & onthly Wage & DID-IV DV: Logarithm & Wage & \\
\hline & Natives & Migrants & Natives & Migrants \\
\hline Treat $\left(a_{1}\right)$ & 0.0477 & 0.2996 & & \\
\hline & $(0.0971)$ & $(0.2058)$ & & \\
\hline Post $\left(a_{2}\right)$ & 0.0403 & $0.4064 * *$ & & \\
\hline & $(0.0533)$ & $(0.1756)$ & & \\
\hline Treat*Post $\left(a_{3}\right)$ & 0.0332 & $-0.5922 * * *$ & & \\
\hline & $(0.0876)$ & $(0.1987)$ & & \\
\hline The logarithm of Syrian Migrant & & & -0.0161 & $-0.0781 * * *$ \\
\hline Population & & & $(0.0174)$ & $(0.0295)$ \\
\hline No. Observations & 8,346 & 863 & 8,346 & 863 \\
\hline R-square & 0.2009 & 0.2098 & & \\
\hline Centered R-square & & & 0.2106 & 0.2374 \\
\hline Weak Identification Test: Cragg-Donald & & & $6,284.730$ & $2,132.969$ \\
\hline Wald F statistic & & & {$[0.000]$} & {$[0.000]$} \\
\hline Wooldridge Robust Score Chi-Square Test & & & 0.1445 & 1.8021 \\
\hline for Endogeneity & & & [0.7037] & {$[0.1798]$} \\
\hline
\end{tabular}


Our results may differ from earlier studies due to various reasons. First, the study by Fakih and Ibrahim (2016) explored the labour outcomes at the aggregate governorate level using a vector autoregressive methodology, while Fallah et al. (2019) have instrumented the main endogenous variablethe share of Syrian refugees, with the distance between the locality and the Zaatari refugee camp. As we mentioned earlier, we instrument, not only with the distance between one refugee camp and the locality but also using the weighted distance between locality and other refugee camps and between the locality and the Syrian governorates. The concluding remarks remain the same for the sample of the migrants in the ILMS, where the Syrian refugee inflows have a positive impact on formal employment and employment, but a negative effect on monthly wages. Moreover, it reduces the probability of labour force participation and employment in a permanent position. In appendix A, we present the estimates for the natives and migrants across socio-economic and demographic groups.

\subsection{Turkey}

In table 5, we report the DID and DID-IV estimates for natives and migrants in Turkey. We should not that report only the coefficient of principal interest, which is the DID estimator. We observe that Syrian refugees had a positive impact on the labour outcomes of natives explored. On the other hand, we find no effect on the labour outcomes of migrants, and in particular, the unemployment and labour force participation, but the Syrian refugee crisis increases the probability for the migrants finding employment in the informal sector under temporary contracts experiencing lower earnings. Thus, we conclude that Syrian refugees displace the migrants but create more employment opportunities and higher earning potential for the natives. Our results are consistent with the study Del Carpio and Wagner (2015) and Aksu et al. (2018), who found that formal employment of Turkish natives noted a significant increase due to Syrian refugee inflows but a negative impact presented for those employed in the informal sector.

Interestingly, we find a negative coefficient of the variable Treat. This finding shows that in the whole period we examine, natives located in the treated areas are less likely to work in the formal sector, in a permanent job, less likely to participate in the labour market, and present lower earning potential. However, the coefficient of the variable Post becomes positive, indicating that following the influx of Syrians, natives have experienced an increase in wages and the probability of being employed in a permanent job and the formal sector. The DID estimator also supports these findings, as we have mentioned above. To test for the parallel trend assumption, we will apply the leads and lags test (see Angrist and Pischke, 2008; Abraham and Sun, 2018 for more details):

$$
y_{i t}=\sum_{j=-q}^{s} \beta_{j} D_{i t+j}+\mu_{i}+\theta_{t}+\varepsilon_{i t}
$$

Where $D_{i t}$ is an indicator showing whether the treatment-policy (Syrian migration) is switched on in year $t$, and the leads and lags of the treatment are expressed respectively by $s$ and $q$. Regarding Jordan, we cannot implement this test since we have only two years in our empirical analysis, in 2010 and 2016. Hence, we cannot test the parallel trend assumption and the validity of the DID model. In all cases, based on the leads and lags test, we accept the null hypothesis, indicating that the parallel trend assumption is not violated and the identification of the DID framework is valid. 
Table 5: DID and DID-IV Estimates for Natives and Migrants in Turkey

\begin{tabular}{|c|c|c|c|c|}
\hline \multirow[t]{2}{*}{ DID } & \multicolumn{2}{|c|}{ DV: Formal Employment } & \multicolumn{2}{|c|}{ DV: Unemployment } \\
\hline & Natives & Immigrants & Natives & Immigrants \\
\hline Treat $\left(a_{1}\right)$ & $\begin{array}{c}-0.0269 * * * \\
(0.0036)\end{array}$ & $\begin{array}{c}-0.0337 * * * \\
(0.0740)\end{array}$ & $\begin{array}{c}-0.0214^{* * *} \\
(0.0019)\end{array}$ & $\begin{array}{c}0.0034 \\
(0.0290)\end{array}$ \\
\hline Post $\left(a_{2}\right)$ & $\begin{array}{c}0.0368^{* * *} \\
(0.0046)\end{array}$ & $\begin{array}{c}-0.2506^{* * *} \\
(0.0765)\end{array}$ & $\begin{array}{c}0.0111^{* * *} \\
(0.0016)\end{array}$ & $\begin{array}{r}0.0343^{* *} \\
(0.0161)\end{array}$ \\
\hline Treat*Post $\left(a_{3}\right)$ & $\begin{array}{c}0.0335^{* * *} \\
(0.0055)\end{array}$ & $\begin{array}{c}-0.3725^{* * *} \\
(0.1272)\end{array}$ & $\begin{array}{c}-0.0076^{* * *} \\
(0.0026)\end{array}$ & $\begin{array}{l}-0.0587 \\
(0.0477)\end{array}$ \\
\hline No. Observations & 202,173 & 542 & 252,612 & 796 \\
\hline R-Square & 0.2840 & 0.5401 & 0.0273 & 0.0368 \\
\hline Leads and Lags Test & $\begin{array}{c}0.3341 \\
{[0.7188]}\end{array}$ & $\begin{array}{c}0.1894 \\
{[0.9096]}\end{array}$ & $\begin{array}{c}42.78 \\
{[0.000]}\end{array}$ & $\begin{array}{c}0.6320 \\
{[0.5316]}\end{array}$ \\
\hline \multirow[t]{2}{*}{ DID-IV } & \multicolumn{2}{|c|}{ DV: Formal Employment } & \multicolumn{2}{|c|}{ DV: Unemployment } \\
\hline & Natives & Immigrants & Natives & Immigrants \\
\hline $\begin{array}{l}\text { The logarithm of Syrian Migrant } \\
\text { Population }\end{array}$ & $\begin{array}{c}0.0113^{* * *} \\
(0.0028)\end{array}$ & $\begin{array}{c}-0.0753^{* *} \\
(0.0303)\end{array}$ & $\begin{array}{c}-0.0055^{* * *} \\
(0.0018)\end{array}$ & $\begin{array}{c}0.0059 \\
(0.0048)\end{array}$ \\
\hline No. Observations & 202,173 & 542 & 252,612 & 796 \\
\hline Centered R-square & 0.2845 & 0.5473 & 0.0296 & 0.0466 \\
\hline $\begin{array}{l}\text { Weak Identification Test: Cragg-Donald } \\
\text { Wald F statistic }\end{array}$ & $\begin{array}{c}81,377.21 \\
{[0.000]}\end{array}$ & $\begin{array}{c}326.367 \\
{[0.000]}\end{array}$ & $\begin{array}{c}88,527.39 \\
{[0.000]}\end{array}$ & $\begin{array}{c}324.042 \\
{[0.000]}\end{array}$ \\
\hline $\begin{array}{l}\text { Wooldridge Robust Score Chi-Square } \\
\text { Test for Endogeneity }\end{array}$ & $\begin{array}{c}2.3548 \\
{[0.1249]}\end{array}$ & $\begin{array}{c}2.1059 \\
{[0.1482]}\end{array}$ & $\begin{array}{c}0.4444 \\
{[0.5051]}\end{array}$ & $\begin{array}{c}0.8196 \\
{[0.3663]}\end{array}$ \\
\hline \multirow[t]{2}{*}{ DID } & \multicolumn{2}{|c|}{ DV: Permanent Contract } & \multicolumn{2}{|c|}{ DV: Labour Force Participation } \\
\hline & Natives & Immigrants & Natives & Immigrants \\
\hline Treat $\left(a_{1}\right)$ & $\begin{array}{c}-0.0239 * * * \\
(0.0037)\end{array}$ & $\begin{array}{r}-0.1080 * \\
(0.0579)\end{array}$ & $\begin{array}{c}-0.0960 * * * \\
(0.0018)\end{array}$ & $\begin{array}{c}-0.1049 * * \\
(0.0386)\end{array}$ \\
\hline Post $\left(a_{2}\right)$ & $\begin{array}{c}-0.0633 * * * \\
(0.0039)\end{array}$ & $\begin{array}{r}-0.0653 * * \\
(0.0294)\end{array}$ & $\begin{array}{c}0.0028 \\
(0.0021)\end{array}$ & $\begin{array}{c}-0.1111^{* *} \\
(0.0504)\end{array}$ \\
\hline Treat*Post $\left(a_{3}\right)$ & $\begin{array}{c}0.0535^{* * *} \\
(0.0058)\end{array}$ & $\begin{array}{c}-0.0477^{* *} \\
(0.0231)\end{array}$ & $\begin{array}{c}0.0362 * * \\
(0.0158)\end{array}$ & $\begin{array}{l}-0.0131 \\
(0.0665)\end{array}$ \\
\hline No. Observations & 162,721 & 504 & 332,386 & 1,022 \\
\hline R-Square & 0.2246 & 0.1442 & 0.3177 & 0.3181 \\
\hline Leads and Lags Test & $\begin{array}{c}1.2130 \\
{[0.1718]}\end{array}$ & $\begin{array}{c}0.6171 \\
{[0.3103]}\end{array}$ & $\begin{array}{c}2.1615 \\
{[0.3192]}\end{array}$ & $\begin{array}{c}1.8472 \\
{[0.3971]}\end{array}$ \\
\hline \multirow[t]{2}{*}{ DID-IV } & \multicolumn{2}{|c|}{ DV: Permanent Contract } & \multicolumn{2}{|c|}{ DV: Labour Force Participation } \\
\hline & Natives & Immigrants & Natives & Immigrants \\
\hline $\begin{array}{l}\text { The logarithm of Syrian Migrant } \\
\text { Population }\end{array}$ & $\begin{array}{c}0.0159 * * * \\
(0.0031)\end{array}$ & $\begin{array}{c}-0.0482^{* *} \\
(0.0227)\end{array}$ & $\begin{array}{c}0.0137 * * * \\
(0.0016)\end{array}$ & $\begin{array}{l}-0.0028 \\
(0.0033)\end{array}$ \\
\hline No. Observations & 162,721 & 504 & 332,386 & 1,022 \\
\hline Centered R-square & 0.2241 & 0.1914 & 0.3346 & 0.3241 \\
\hline $\begin{array}{l}\text { Weak Identification Test: Cragg-Donald } \\
\text { Wald F statistic }\end{array}$ & $\begin{array}{c}49,124.35 \\
{[0.000]}\end{array}$ & $\begin{array}{r}334.428 \\
{[0.000]}\end{array}$ & $\begin{array}{c}58,925.41 \\
{[0.000]}\end{array}$ & $\begin{array}{c}1,266.778 \\
{[0.000]}\end{array}$ \\
\hline $\begin{array}{l}\text { Wooldridge Robust Score Chi-Square } \\
\text { Test for Endogeneity }\end{array}$ & $\begin{array}{c}0.2275 \\
{[0.6334]}\end{array}$ & $\begin{array}{c}0.0260 \\
{[0.8720]}\end{array}$ & $\begin{array}{c}2.2029 \\
{[0.1377]}\end{array}$ & $\begin{array}{c}2.5527 \\
{[0.1105]}\end{array}$ \\
\hline
\end{tabular}


According to the Cragg-Donald Wald F-statistic weak instrument test and its associated $p$-values, we reject the null hypothesis, concluding that the instrument is valid. Based on the Wooldridge robust score chi-square test and the $p$-values, we also accept the null hypothesis, implying that the instrument employed is exogenous. In appendix B, we report the estimates across demographic and socio-economic groups.

Table 5: (Cont.) DID and DID-IV Estimates for Natives and Migrants in Turkey

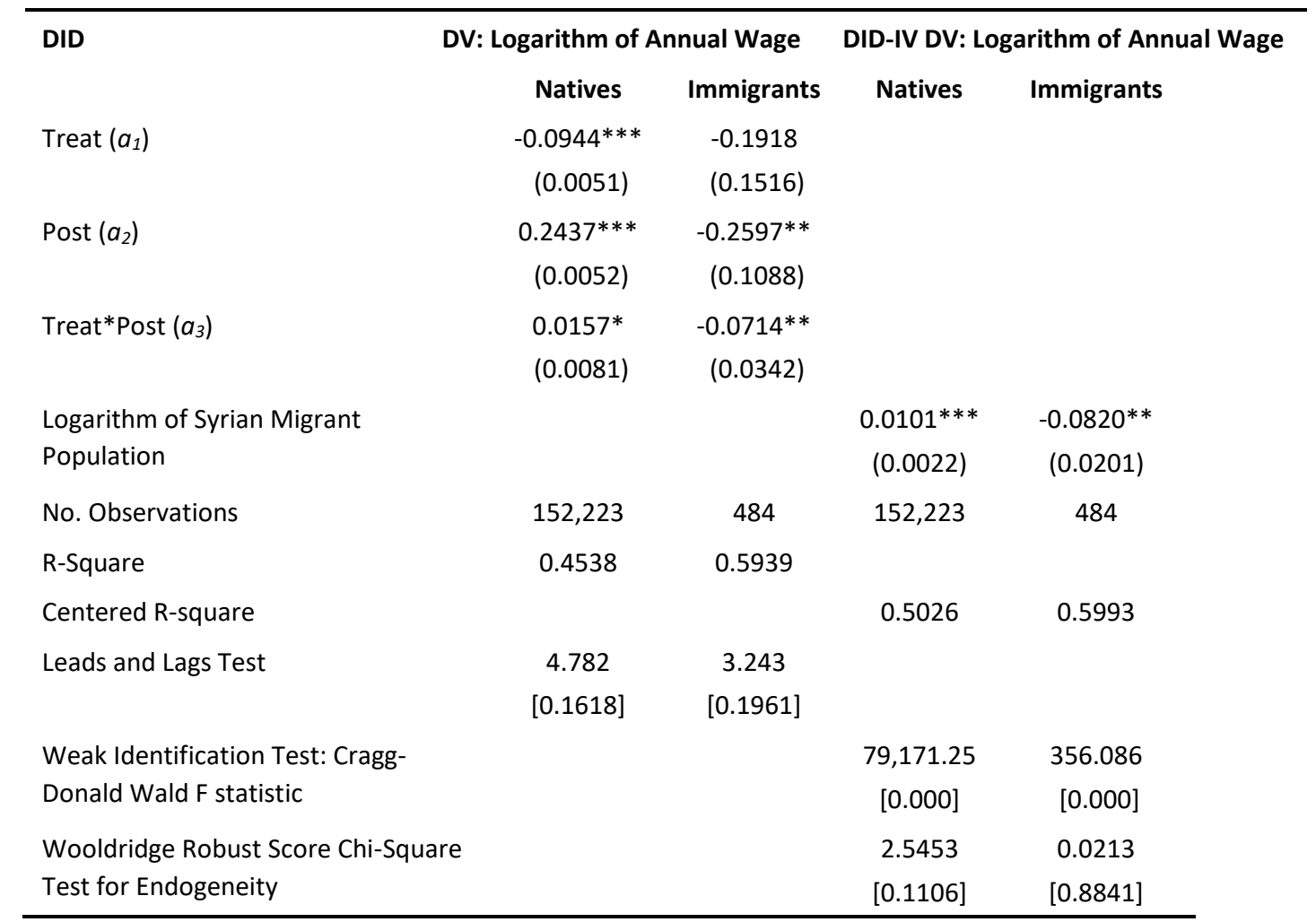

Wild Bootstrap Combined with Regional-Level Clustered Standard Errors in Parenthesis, P-values within brackets

$* * *, * *$ and $*$ denote significance at $1 \%, 5 \%$ and $10 \%$ level.

\section{CONCLUSIONS}

This study has attempted to estimate the impact of the Syrian refugee influx on labour outcomes in Jordan and Turkey. The results are mixed and vary by country, labour outcomes, migrant status and socio-economic groups. In particular, in Turkey, the results show that natives located in areas that host most of the Syrian refugees, experience higher employment and wage rates, in contrast to migrants that report lower levels of wages and more unfavourable labour market conditions. The inequalities in the two countries explored are persistent in the most vulnerable groups, such as females, low educated and employed in low-skilled jobs.

We can attribute the differences in the findings across the countries to the availability of data and the surveys employed in the analysis. In particular, for Jordan, we used 2 periods and six years apart in 2010 and 2016, and for Turkey, we have used five consecutive years 2009-2013. One explanation for the differences in the estimates is that given the period of the data employed in the empirical work, we investigate the impact of the Syrian refugees on the labour outcomes in Turkey in the short-run period and the effect in Jordan in the medium-run period. 
Thus, one explanation is that Syrian refugees are substitutes for native workers, at least in the short run, because the immigrants may not transfer immediately to the host economy their human capital stocks and skills. Therefore, in the medium term, we may observe a negative effect if the refugees are substitutes but not complements in the production process. The period of investigation for Jordan refers to the medium-term horizon, where we find that the Syrian refugee crisis has created employment opportunities in the formal sector for both natives and migrants. However, that was operationalized under temporary contracts associated with lower wages for the migrants.

The medium-run impact in Jordan is positive for both natives and migrants in terms of employment opportunities in the formal sector but these are associated with temporary contracts, as well as lower earning potential for migrants. On the other hand, in Turkey, the short-run impact of Syrian migration is positive for the labour outcomes of natives but negative for migrants.

However, the study is not without drawbacks. The first limitation is that we employ cross-sectional surveys, and we cannot follow the same individuals across time to control for unobserved heterogeneity and omitted-variable bias. Second, due to information recorded in the HLFS in Turkey, we have limited the analysis to 2009-2013. The issue is that most of the Syrian refugees were located in camps up to 2013, while the following years were able to move across Turkey and relocate to other areas outside camps. This most likely has a significant impact on the labour outcomes explored, implying that our findings may underestimate the impact, positive or negative, of the Syrian refugees. For instance, while we find a positive effect on the formal employment and wages of natives, the impact can be lower or even reversed in some areas that host a large number of Syrians. Thus, HLFS and other surveys should record the nationality and ethnicity of the respondent to identify the migrant status. Then, this can be expanded into an analysis where not only first-generation migrants but also considering second and higher generations of migrants. In line with this, we have no information about the length of residence of migrants in the host countries, which can be a strong driver of economic integration. Migrants living many years in the host country have acquired the language proficiency, necessary job skills and have adjusted to the cultural and social norms of the host countries (Bakker et al., 2017; Dustmann et al., 2017). This adaptation and acculturation imply that the impact of Syrian refugees on their labour outcomes will be weaker compared to the migrants that have later relocated to the host country.

The findings of this study have various policy implications. National governments and public authorities should devise labour market strategies that aim to increase flexibility, on the one hand, allowing market forces to allocate resources and firms to thrive, while also providing targeted support through active labour market policies, such as employment support programmes, training programmes, wage subsidies, labour market intermediation services, training and skill upgrading, and supporting SmallMedium Enterprises (SME) development with the support of value chain analysis. These policies can be aimed at provinces, areas and governorates with a high proportion of refugees to counteract the detrimental effects of informal Syrian labour on employment and wages.

The challenges that the host countries face require strong international support, delivered in a unified and coordinated way by international donors and relevant national and subnational authorities. Sound economic policies to ensure macroeconomic stability are a prerequisite for dealing with labour market challenges and harnessing the positive effects brought about by the refugee inflows.

Authorities and policymakers should address the informal sector and formalize it to eliminate informal employment. The informal economic sector employs a large share of low-skilled and low-wage workers, and given their background and status as refugees it is no surprise that nearly all Syrian refugees are informally employed in this sector. However, because of their willingness to accept lower wages and poorer working conditions, refugees have a comparative advantage over natives who may compete for the same employment.

Furthermore, the informal economy because of its unregulated and highly competitive nature, creates unsustainable conditions for workers. The informal sector is characterized by low productivity and 
is associated with few direct contributions to the national economy. Minimum wage limits are not respected in the informal sector in general, and a large number of Syrian refugees, as well as many locals in the host countries we explore, are paid significantly less than the stated minimum rates. In addition to tackling informal employment more broadly, direct and short-term solutions to this problem should be developed.

The private sector should encourage the employment of Syrian refugees in the formal sector that can address the problem of informalization and the unfavourable labour conditions associated with the informal labour market. Controlled integration of Syrian refugee employees into the labour market has the ability to alleviate some of the current labour market tensions and distortions. Private sector encouragement may play a key part in such a strategy, but it must be closely coordinated with regulatory system adaptations and the authorities that issue work permits.

Any successful strategy must be based on actual scenarios and should be guided by two main premises. First, Syrian refugees will most likely remain in host nations for many years, having an impact on the labour market; and second, attention should be paid to how Syrian refugees' participation in the host country's labour market can be formalized in ways that benefit the domestic economy. Additionally, given the possibility of a lengthy Syrian refugee scenario in the host countries, as well as the need to avoid even greater obstacles when development funds and international support are reduced, the sooner this issue is addressed, the better for both Syrian refugees and natives, and the host economies.

Another policy involves the maximization of the aid economy's short-term employment potential and coordinating actions between the national government and the international community. High unemployment rates among natives, particularly youth, and Syrian refugees should be addressed through boosting short-term job and capacity-building possibilities related to development aid organizations' activities. This might directly provide new employment possibilities for natives and locals as well as relieve pressure on other sections of the labour market by assisting Syrian refugees with their livelihoods. It may also help to enhance local economies and, as a result, create more jobs.

While local governments have generously provided schools for Syrian children, the low schooling enrolment rates among Syrian children has both short- and long-term labour market implications. First, it adds to current levels of child labour, and second, it has implications for long-term work options for children who are not in school, perhaps in the domestic labour market. Strengthening the national framework for child labour can aid in the implementation of a comprehensive and integrated labour market policy.

Policymakers should maximize the aid economy's potential for job creation, as well as encourage the participation of foreign actors such as UN agencies, particularly the UN Refugee Agency (UNHCR), who are aware of the need to make aid more effective for local development. This potential, however, has yet to be completely realized. As a result, sourcing goods and services locally whenever possible is a fast and straightforward approach to kick start an economy while also triggering a multiplier effect that leads to job creation. Providing services that facilitate an expanded number of contracts between firms in host countries and the international community would demonstrate the impact of job creation on engendering stability and enriching local communities. When possible, doing business with SMEs and local businesses can help to expand employment and other opportunities in the host community. Furthermore, it is critical to lessen refugees' reliance on humanitarian aid and to equip them with the skills necessary for selfsufficiency when they return home.

Work permits should be granted to Syrians to work in selected sectors. If Syrian refugees' access to legal work is not resolved, the domestic labour market will become more deregulated, negatively impacting both natives and Syrians. Certain jobs are not appealing to native workers and as a result of labour shortages are filled by migrants. Jobs in low-skilled manufacturing, agriculture, services, or construction, as well as in the Qualified Industrial Zones, fall into this category. Work permits for Syrians 
in these occupations should be issued to counter current labour demand while maintaining labour market regulation, as these jobs might be filled informally in any case.

Future studies may exploit similar identification strategies to explore the effect of forced migration on subjective well-being, such as life satisfaction, happiness, psychological well-being and mental health, as well as, on cultural, social values and norms in the MENA region countries. Therefore, further research is needed to understand a more complete picture of the Syrian refugee crisis, and its impact on the local population and economies in the countries we explored, and also in other countries affected by the crisis, including Lebanon, Iraq and European countries. Further analysis will provide a better understanding of the long term effects of the refugee crisis on various economic, demographic and socio-cultural outcomes of both natives and migrants.

\section{NOTLAR}

1 https://data2.unhcr.org/en/situations/syria, Access Date: 10.03.2020.

2 Even though, a large influx of Syrian refugees has been recorded in Lebanon, due to data unavailability we will not explore the impact of Syrian refugees.

${ }^{3}$ https://reliefweb.int/sites/reliefweb.int/files/resources/Syrian Refugees Admn3 Dec2016 A3L.pdf, Access Date: 19.01.2020.

https://reliefweb.int/report/jordan/unhcr-jordan-factsheet-january-december-2018, Access Date: 11.03.2020.

${ }^{4}$ https://multeciler.org.tr/eng/numbers-of-syrians-in-turkey-july-2020, Access Date: 23.08.2020.

${ }^{5}$ https://reliefweb.int/sites/reliefweb.int/files/resources/syrian border crossings.pdf, Access Date: 10.01.2020.

\section{AUTHOR STATEMENT}

\section{Research and Publication Ethics Statement}

This study has been prepared in accordance with the ethical principles of scientific research and publication.

\section{Author Contribution}

All authors have contributed to the study equally.

\section{Conflict of Interest}

There is no conflict of interest arising from the study for the authors or third parties.

\section{Declaration of Support}

This study has been supported by the Economic Research Forum (ERF) under the call "Micro-Level Analysis of the Impact of Violent Conflict on Lives and Livelihoods in the MENA Region" and has benefited from both financial and intellectual support. The contents and recommendations do not necessarily reflect ERF's views. The authors are grateful for the financial support received. Furthermore, this paper has been produced benefiting from the Marie Skłodowska-Curie Action 2236 Co-Funded Brain Circulation Scheme2 (CoCirculation2) of TÜBITAK (Project No: 119C017), which has been funded under the FP7-PEOPLE-2011-COFUND call of the 7th Framework Programme. The authors are grateful for the financial support received. However, the entire responsibility of the paper belongs to the owners of the paper. The financial support received from the Scientific and Technological Research Council of Turkey (TÜBITAK) does not mean that the context of the paper is approved in a scientific sense by TÜBITAK. An earlier version is published as a discussion working paper from the funded institution the Economic Research Forum (ERF), which is acknowledged in the manuscript and is available at;

- $\quad$ https://erf.org.eg/publications/the-impact-of-syrian-conflict-and-the-refugee-crisis-on-labour-marketoutcomes-of-host-countries/

- $\quad$ https://ideas.repec.org/p/erg/wpaper/1435.html. This study is an update of the working paper. 
Acknowledgements: The authors would like to thank the Editor and an anonymous reviewer for their valuable suggestions and constructive comments that greatly contributed to the improvement of the quality of this paper. Any remaining errors or omissions remain the responsibility of the authors. Furthermore, the authors would like to thank Professor Semih Tumen and the participants in the online workshop "The Micro-Level Analysis of the impact of Violent Conflict on Lives and Livelihoods" on 26th October 2020, organized by the Economic Research Forum (ERF), for the valuable comments and feedback.

\section{REFERENCES}

Abraham, S. and L. Sun (2018), Estimating Dynamic Treatment Effects in Event Studies with Heterogeneous Treatment Effects. Papers 1804.05785, arXiv.org.

Aksu, E., R. Erzanand, M. G. Kırdar (2018), The impact of mass migration of Syrians on the Turkish Labor Market (No. 1815), Working Paper. IZA DP No. 12050, Bonn, Germany.

Al Sharif, O. (2017), Have GCC countries turned their backs on Jordan? Al-Monitor, January 31,2017, https://www.almonitor.com/originals/2017/01/jordan-economic-crisis-aid-donors-gcc-regional-turmoil.html, Access Date: 18.02 .2020

Altonji, J. G. and D. Card (1991), The Effects of Immigration on the Labor Market Outcomes of Less-Skilled Natives. In Immigration, Trade, and the Labor Market, J. Abowd and R. B. Freeman (Eds.) University of Chicago Press, 201-234.

Angrist, J. D. and J. S. Pischke (2008), Mostly Harmless Econometrics: An empiricist's Companion, Princeton University Press.

Autor, D. H. (2003), “Outsourcing at Will: The Contribution of Unjust Dismissal Doctrine to the Growth of Employment Outsourcing", Journal of labor economics, 21(1), 1-42.

Baez, J. (2011), "Civil Wars Beyond their Borders: The Human Capital and Health Consequences of Hosting Refugees." Journal of Development Economics, 96(2), 391-408.

Bahçekapılı, C. and B. Çetin (2015), "The Impacts of Forced Migration on Regional Economies: The Case of Syrian Refugees in Turkey", International Business Research, 8, 1-15.

Bakker, L., J. Dagevos, G. Engbersen (2017), "Explaining the refugee gap: a longitudinal study on labour market participation of refugees in the Netherlands", Journal of Ethnic and Migration Studies, 43(11), 1775-1791.

Baklacioğlu, N. O. (2017), "Gendering Migration Across Euro-Mediterranean Borders: Syrian refugee women on the way to the Europe", Turkish Journal of Middle Eastern Studies, 4(2), 75-101.

Bartel, A. P. (1989), “Where Do the New United-States Immigrants Live?”, Journal of Labor Economics, 7(4), 371-391.

Beine, M., F. Docquier and Ç. Özden (2011), “Diasporas”, Journal of Development Economics, 95(1), 30-41.

Black, D., S. G., Sanders, E. J. Taylor and L. J. Taylor (2015), "The Impact of the Great Migration on Mortality of African Americans: Evidence from the Deep South", American Economic Review, 105(2), 477-503.

Borjas, G. J. and J. Monras (2017), "The Labour Market Consequences of Refugee Supply Shocks", Economic Policy, 32(91), 361-413.

Brian, T. and Laczko, F. (2016), "Introduction: Migrant deaths around the world in 2015", Fatal Journeys, 2, 1-30.

Cagaptay, S. and B. Menekse (2014), "The impact of Syrias's refugees on Southern Turkey", Washington Institute for Near East Policy.

Ceritoglu, E., H. B. G. Yunculer, H. Torun and S. Tumen (2017), “The Impact of Syrian Refugees on Natives' Labor Market Outcomes in Turkey: Evidence from a Quasi-Experimental Design", IZA Journal of Labor Policy, 6(1), 5.

Del Carpio, X. V. and M. Wagner (2015), "The Impact of Syrians Refugees on the Turkish Labor Market, The World Bank", Policy Research Working Paper 7402.

Duruel, M. (2017), "Suriyeli Sığınmacıların Türk Emek Piyasasına Etkileri Fırsatlar ve Tehditler", Uluslararası Ekonomik Araştırmalar Dergisi, 3(2), 207-222. 
Dustmann, C., F. Fasani, T. Frattini, L. Minale and U. Schönberg (2017), “On the Economics and Politics of Refugee Migration, Economic Policy", 32(91), 497-550.

Esen, O. and A. Oğuş Binatlı (2017), "The Impact of Syrian Refugees on the Turkish Economy: Regional Labour Market Effects", Social Sciences, 6(4), 129.

Fakih, A. and M. Ibrahim (2016), "The impact of Syrian refugees on the labor market in neighboring countries: empirical evidence from Jordan", Defence and Peace Economics, 27(1), 64-86.

Fallah, B., C. Krafftand, J. Wahba (2019), "The Impact of Refugees on Employment and Wages in Jordan", Journal of Development Economics, 139, 203-216.

Işcan, i. H. and M. Çakir (2019), "Türkiye'deki Sığınmacı ve Mültecilerin Türk İşgücü Piyasasına Etkisi: Bir Saha Araştırması", Sosyal Politika Çalışmaları Dergisi, 19(43), 177-236.

Kreibaum, M. (2016), "Their Suffering, Our Burden? How Congolese Refugees Affect the Ugandan Population”, World Development, 78(C), 262-287.

Lenner, K. (2016), "Blasts from the Past: Policy Legacies and Policy Memories in the Making of the Jordanian Response to the Syrian Refugee Crisis", EUI working Papers, MWP red number series, 32.

Open Access Micro Data Initiative (OAMDI), (2019), Labor Market Panel Surveys (LMPS), http://erf.org.eg/dataportal/, Version 4.0 of Licensed Data Files; ILMPS, Egypt: Economic Research Forum (ERF).

Özkarsli, F. (2015), "Mardin'de Enformel İstihdamda Çalışan Suriyeli Göçmenler”, Birey ve Toplum Sosyal Bilimler Dergisi, 5(1), 175-192.

Peri, G. (2012), "The Effect of Immigration on Productivity: Evidence from US States", The Review of Economics and Statistics, 94(1), 348-358.

Ruiz, I., and C Vargas-Silva (2015), "The Labor Market Impacts of Forced Migration", American Economic Review, 105(5), 581-586.

Salemi, C., J. Bowmanand, J. Compton (2018), "Services for Syrian Refugee Children and Youth in Jordan: Forced Displacement, Foreign Aid, and Vulnerability", in Economic Research Forum Working Paper Series, No. 1188, Cairo, Egypt.

Simon, J. L. (1966), "The Price Elasticity of Liquor in the U.S. and a Simple Method of Determination", Econometrica, 34, 193-205.

Sinnott, R. W. (1984), "Virtues of the Haversine", Sky and Telescope, 68(2), 159.

Snow, J. (1855), "On the mode of communication of cholera", London: John Churchill, 2nd edition, 1855. http://archive.org/details/b28985266. Access Date: 17.03.2020.

Snow, J. (1856), "Cholera and the Water Supply in the South District of London in 1854", Journal of Public Health and Sanitary Review, 2, 239-257.

Stave, S. E. and S. Hillesund (2015), "Impact of the Influx of Syrian Refugees on the Jordanian Labor Market: Findings from the Governorates of Amman, Irbid and Mafraq." ILO and FAFO. https://www.ilo.org/wcmsp5/groups/public/\%2D\%2D-arabstates/\%2D\%2D-robeirut/documents/publication/wcms 364162.pdf, Access Date: 14.01.2020.

Tumen, S. (2018), The Impact of Low-Skill Refugees on Youth Education, HiCN Working Paper No. 283, Households in Conflict Network, The Institute of Development Studies - at the University of Sussex - Falmer - Brighton.

United Nations High Commissioner for Refugees (UNHCR) (2019), “Global Trends, Forced Displacement in 2019". https://www.unhcr.org/5ee200e37.pdf, Access Date: 14.01.2020.

Wooldridge, J. M. (1995), "Score Diagnostics for Linear Models Estimated by two Stage Least Squares", In Advances in Econometrics and Quantitative Economics: Essays in Honor of Professor C. R. Rao, (Eds.) G. S. Maddala, P. C. B. Phillips, and T. N. Srinivasan, 66-87, Oxford: Blackwell. 


\section{APPENDIX A: Additional Estimates for Jordan}

In tables A1-A2 we report the DID-IV estimates by gender, education, age, formality and job skills. As high education, we define those who have completed the high school and upper as most of the respondents explored in these countries have educational attainment up to a secondary school ranging between 75-80 percent. As high skilled persons, we consider those who are managers; technicians and associated professionals and skilled agricultural workers, while the low-skilled group comprises those who are support workers; working in sales and trade and those employed in elementary occupations. The estimates across natives and migrants share some common characteristics. In particular, males, high educated, and those aged between 36-64 are more likely to be employed in the formal sector, while there is no effect on low-educated and young respondents. Furthermore, the refugee crisis has a positive effect on the probability of migrants being employed in the formal sector for both high and low skilled jobs. We derive similar conclusions for unemployment; however, we find that the low-educated migrants and aged 36-64 are more likely to be unemployed. About job security and whether the respondents work in a job with a permanent contract, we find a negative impact on native males and low educated but a positive effect for those employed in the formal sector. On the other hand, migrants are in a more difficult position, because both formal and informal workers are more likely to be employed in a temporary job. Regarding wages, we find no effect except for natives working in lowskilled jobs and are negatively affected, while high educated people experience an increase in their monthly wages. Migrants, on the other hand, experience a fall in wages, and in particular, males, low educated, young and employed in the informal sector.

Overall, Syrian refugees may increase the formal employment opportunities for both natives and migrants but displace young, low educated and informal migrant workers with low skills in terms of wages. This finding indicates that Syrian refugees are substitutes to the migrants and specific to low educated and low-skilled workers, but complements to the natives and to highly educated and high-skilled workers. Theoretically, we could expect that lower wages in the informal sector may result in substitution from formal to informal workers. However, we found a positive impact on formal employment for both natives and migrants, which could be attributed to the lower production costs that expand the output and increase the demand for formal workers. Natives in Jordan could take advantage of the low costs of Syrian refugee labour that creates new jobs. Nevertheless, we could argue that the Syrian refugee influx has created many low-skilled jobs that could have been available to Jordanians. This argument is especially the case of low educated, low-skilled and youth with no working experience, who have to compete with refugees willing to accept considerably lower wages (Stave and Hillesund, 2015). 
Table A1: DID-IV Estimates for Natives in Jordan Across Groups

\begin{tabular}{|c|c|c|c|c|c|}
\hline Male & $\begin{array}{l}\text { DV: Formal } \\
\text { Employment }\end{array}$ & $\begin{array}{c}\text { DV: } \\
\text { Unemployment }\end{array}$ & $\begin{array}{c}\text { DV: Permanent } \\
\text { Contract }\end{array}$ & $\begin{array}{l}\text { DV: Labour } \\
\text { Force } \\
\text { Participation }\end{array}$ & $\begin{array}{l}\text { DV: Logarithm of } \\
\text { Monthly Wage }\end{array}$ \\
\hline The logarithm of Syrian & $0.0035^{* *}$ & $-0.0028 * * *$ & $-0.0137 * * *$ & $-0.0116 * * *$ & 0.0209 \\
\hline Migrant Population & $(0.0016)$ & $(0.0009)$ & $(0.0042)$ & $(0.0022)$ & $(0.0161)$ \\
\hline No. Observations & 8,378 & 15,234 & 8,382 & 16,214 & 6,098 \\
\hline Centered R-square & 0.8011 & 0.0345 & 0.3887 & 0.2331 & 0.2089 \\
\hline \multicolumn{6}{|l|}{ Female } \\
\hline The logarithm of Syrian & 0.0018 & 0.0015 & -0.0012 & $-0.0051 * *$ & 0.0061 \\
\hline Migrant Population & $(0.0035)$ & $(0.0018)$ & $(0.0039)$ & $(0.0020)$ & $(0.0242)$ \\
\hline No. Observations & 2,370 & 15,600 & 2,373 & 16,408 & 2,248 \\
\hline Centered R-square & 0.8391 & 0.1136 & 0.2415 & 0.3060 & 0.3065 \\
\hline High Education & $\begin{array}{l}\text { DV: Formal } \\
\text { Employment }\end{array}$ & $\begin{array}{c}\text { DV: } \\
\text { Unemployment }\end{array}$ & $\begin{array}{c}\text { DV: Permanent } \\
\text { Contract }\end{array}$ & $\begin{array}{l}\text { DV: Labour } \\
\text { Force } \\
\text { Participation }\end{array}$ & $\begin{array}{l}\text { DV: Logarithm of } \\
\text { Monthly Wage }\end{array}$ \\
\hline The logarithm of Syrian & $0.0047^{* *}$ & $-0.0055^{* *}$ & -0.0027 & $-0.0159 * * *$ & $0.0110^{*}$ \\
\hline Migrant Population & $(0.0022)$ & $(0.0024)$ & $(0.0025)$ & $(0.0033)$ & $(0.0062)$ \\
\hline No. Observations & 3,610 & 7,104 & 3,612 & 7,145 & 3,085 \\
\hline Centered R-square & 0.7581 & 0.1016 & 0.1262 & 0.1521 & 0.2005 \\
\hline \multicolumn{6}{|l|}{ Low Education } \\
\hline The logarithm of Syrian & 0.0019 & -0.0017 & $-0.0161 * * *$ & $-0.0092 * * *$ & 0.0091 \\
\hline Migrant Population & $(0.0026)$ & $(0.0015)$ & $(0.0051)$ & $(0.0030)$ & $(0.0102)$ \\
\hline No. Observations & 7,138 & 23,730 & 7,143 & 25,477 & 5,261 \\
\hline Centered R-square & 0.8106 & 0.0323 & 0.4059 & 0.3752 & 0.1304 \\
\hline Age 16-35 & $\begin{array}{l}\text { DV: Formal } \\
\text { Employment }\end{array}$ & $\begin{array}{c}\text { DV: } \\
\text { Unemployment }\end{array}$ & $\begin{array}{c}\text { DV: Permanent } \\
\text { Contract }\end{array}$ & $\begin{array}{l}\text { DV: Labour } \\
\text { Force } \\
\text { Participation }\end{array}$ & $\begin{array}{l}\text { DV: Logarithm of } \\
\text { Monthly Wage }\end{array}$ \\
\hline The logarithm of Syrian & 0.0007 & 0.0025 & $-0.0089 * *$ & $-0.0077 * * *$ & 0.0045 \\
\hline Migrant Population & $(0.0029)$ & $(0.0024)$ & $(0.0042)$ & $(0.0021)$ & $(0.0081)$ \\
\hline No. Observations & 6,405 & 18,100 & 6,409 & 19,100 & 4,466 \\
\hline Centered R-square & 0.8194 & 0.0631 & 0.3337 & 0.4179 & 0.2034 \\
\hline \multicolumn{6}{|l|}{ Age 36-64 } \\
\hline The logarithm of Syrian & $0.0084^{* *}$ & $-0.0036 * *$ & $-0.0145^{* * *}$ & $-0.0095^{* *}$ & 0.0101 \\
\hline Migrant Population & $(0.0041)$ & $(0.0015)$ & $(0.0045)$ & $(0.0044)$ & $(0.0097)$ \\
\hline No. Observations & 4,343 & 12,734 & 4,346 & 13,522 & 3,880 \\
\hline Centered R-square & 0.7881 & 0.0210 & 0.4130 & 0.4325 & 0.2088 \\
\hline
\end{tabular}




\begin{tabular}{|c|c|c|c|}
\hline Formal Sector & & $\begin{array}{l}\text { DV: Permanent } \\
\text { Contract }\end{array}$ & $\begin{array}{c}\text { DV: Logarithm of } \\
\text { Wage }\end{array}$ \\
\hline The logarithm of Syrian & & 0.0026 & 0.0045 \\
\hline Migrant Population & & $(0.0082)$ & $(0.0084)$ \\
\hline No. Observations & & 6,011 & 5,023 \\
\hline Centered R-square & & 0.1864 & 0.1701 \\
\hline \multicolumn{4}{|l|}{ Informal Sector } \\
\hline The logarithm of Syrian & & $-0.0268 * * *$ & $0.0226^{* * *}$ \\
\hline Migrant Population & & $(0.0073)$ & $(0.0090)$ \\
\hline No. Observations & & 4,744 & 3,323 \\
\hline Centered R-square & & 0.3863 & 0.1233 \\
\hline High Skill & $\begin{array}{l}\text { DV: Formal } \\
\text { Employment }\end{array}$ & $\begin{array}{l}\text { DV: Permanent } \\
\text { Contract }\end{array}$ & $\begin{array}{l}\text { DV: Logarithm of } \\
\text { Wage }\end{array}$ \\
\hline The logarithm of Syrian & 0.0021 & $0.0106^{*}$ & -0.0038 \\
\hline Migrant Population & $(0.0023)$ & $(0.0054)$ & $(0.0078)$ \\
\hline No. Observations & 3,601 & 3,604 & 2,638 \\
\hline Centered R-square & 0.7958 & 0.3365 & 0.3193 \\
\hline \multicolumn{4}{|l|}{ Low Skill } \\
\hline Logarithm of Syrian & 0.0035 & -0.0038 & $-0.0234 *$ \\
\hline Migrant Population & $(0.0048)$ & $(0.0078)$ & (0.0108) \\
\hline No. Observations & 7,147 & 7,151 & 5,708 \\
\hline Centered R-square & 0.8052 & 0.3990 & 0.3990 \\
\hline
\end{tabular}

Wild Bootstrap Combined with Regional-Level Clustered Standard Errors in Parenthesis, P-values within brackets, ***, ** and * denote significance at $1 \%, 5 \%$ and $10 \%$ level. 
Table A2: DID-IV Estimates for Migrants in Jordan Across Groups

\begin{tabular}{|c|c|c|c|c|c|}
\hline Male & $\begin{array}{l}\text { DV: Formal } \\
\text { Employment }\end{array}$ & $\begin{array}{c}\text { DV: } \\
\text { Unemployment }\end{array}$ & $\begin{array}{c}\text { DV: Permanent } \\
\text { Contract }\end{array}$ & $\begin{array}{l}\text { DV: Labour Force } \\
\text { Participation }\end{array}$ & $\begin{array}{l}\text { DV: Logarithm of } \\
\text { Monthly Wage }\end{array}$ \\
\hline $\begin{array}{l}\text { The logarithm of } \\
\text { Syrian Migrant } \\
\text { Population }\end{array}$ & $\begin{array}{c}0.0188^{* * *} \\
(0.0048)\end{array}$ & $\begin{array}{l}-0.0177^{*} \\
(0.0093)\end{array}$ & $\begin{array}{l}-0.0314^{*} \\
(0.0187)\end{array}$ & $\begin{array}{c}-0.0302^{* * *} \\
(0.0040)\end{array}$ & $\begin{array}{c}-0.0926 * * * \\
(0.0296)\end{array}$ \\
\hline No. Observations & 821 & 1,803 & 821 & 2,005 & 703 \\
\hline Centered R-square & 0.8736 & 0.0458 & 0.4431 & 0.2906 & 0.2201 \\
\hline \multicolumn{6}{|l|}{ Female } \\
\hline $\begin{array}{c}\text { The logarithm of } \\
\text { Syrian Migrant } \\
\text { Population }\end{array}$ & $\begin{array}{l}-0.0350 \\
(0.0348)\end{array}$ & $\begin{array}{l}-0.0011 \\
(0.0030)\end{array}$ & $\begin{array}{c}-0.0523 * * \\
(0.0217)\end{array}$ & $\begin{array}{l}-0.0041 \\
(0.0073)\end{array}$ & $\begin{array}{l}-0.0134 \\
(0.0117)\end{array}$ \\
\hline No. Observations & 166 & 1,561 & 166 & 1,725 & 160 \\
\hline Centered R-square & 0.9803 & 0.0378 & 0.9806 & 0.0982 & 0.8781 \\
\hline High Education & $\begin{array}{l}\text { DV: Formal } \\
\text { Employment }\end{array}$ & $\begin{array}{c}\text { DV: } \\
\text { Unemployment }\end{array}$ & $\begin{array}{c}\text { DV: Permanent } \\
\text { Contract }\end{array}$ & $\begin{array}{l}\text { DV: Labour Force } \\
\text { Participation }\end{array}$ & $\begin{array}{l}\text { DV: Logarithm of } \\
\text { Monthly Wage }\end{array}$ \\
\hline $\begin{array}{c}\text { The logarithm of } \\
\text { Syrian Migrant } \\
\text { Population }\end{array}$ & $\begin{array}{l}0.0075^{* *} \\
(0.0038)\end{array}$ & $\begin{array}{l}-0.0036 \\
(0.0031)\end{array}$ & $\begin{array}{l}-0.0129 \\
(0.0108)\end{array}$ & $\begin{array}{c}-0.0270 * * * \\
(0.0075)\end{array}$ & $\begin{array}{l}-0.0251 \\
(0.0228)\end{array}$ \\
\hline No. Observations & 249 & 420 & 249 & 427 & 212 \\
\hline Centered R-square & 0.8609 & 0.0943 & 0.1262 & 0.3787 & 0.3808 \\
\hline \multicolumn{6}{|l|}{ Low Education } \\
\hline $\begin{array}{c}\text { The logarithm of } \\
\text { Syrian Migrant } \\
\text { Population }\end{array}$ & $\begin{array}{c}0.0072 \\
(0.0177)\end{array}$ & $\begin{array}{l}0.0115^{*} \\
(0.0063)\end{array}$ & $\begin{array}{l}-0.0418^{*} \\
(0.0220)\end{array}$ & $\begin{array}{c}-0.0178 * * * \\
(0.0054)\end{array}$ & $\begin{array}{c}-0.0397^{* *} \\
(0.0158)\end{array}$ \\
\hline No. Observations & 738 & 2,944 & 738 & 3,303 & 651 \\
\hline Centered R-square & 0.8960 & 0.0647 & 0.4598 & 0.3752 & 0.1459 \\
\hline Age 16-35 & $\begin{array}{l}\text { DV: Formal } \\
\text { Employment }\end{array}$ & $\begin{array}{c}\text { DV: } \\
\text { Unemployment }\end{array}$ & $\begin{array}{l}\text { DV: Permanent } \\
\text { Contract }\end{array}$ & $\begin{array}{l}\text { DV: Labour Force } \\
\text { Participation }\end{array}$ & $\begin{array}{l}\text { DV: Logarithm of } \\
\text { Monthly Wage }\end{array}$ \\
\hline $\begin{array}{c}\text { The logarithm of } \\
\text { Syrian Migrant } \\
\text { Population }\end{array}$ & $\begin{array}{c}0.0056 \\
(0.0045)\end{array}$ & $\begin{array}{c}0.0057 \\
(0.0063)\end{array}$ & $\begin{array}{c}-0.0397^{* *} \\
(0.0194)\end{array}$ & $\begin{array}{c}-0.0199 * * * \\
(0.0042)\end{array}$ & $\begin{array}{l}-0.0498 * \\
(0.0282)\end{array}$ \\
\hline No. Observations & 551 & 2,098 & 551 & 2,297 & 504 \\
\hline Centered R-square & 0.9059 & 0.0710 & 0.4144 & 0.4302 & 0.1794 \\
\hline \multicolumn{6}{|l|}{ Age 36-64 } \\
\hline $\begin{array}{c}\text { The logarithm of } \\
\text { Syrian Migrant } \\
\text { Population }\end{array}$ & $\begin{array}{l}0.0044 * \\
(0.0023)\end{array}$ & $\begin{array}{l}0.0179 * * \\
(0.0076)\end{array}$ & $\begin{array}{l}-0.0368^{*} \\
(0.0195)\end{array}$ & $\begin{array}{c}-0.0201 * * * \\
(0.0055)\end{array}$ & $\begin{array}{l}-0.0051 \\
(0.0274)\end{array}$ \\
\hline No. Observations & 436 & 1,266 & 436 & 1,433 & 359 \\
\hline Centered R-square & 0.8376 & 0.0750 & 0.4939 & 0.4886 & 0.2995 \\
\hline
\end{tabular}




\begin{tabular}{|c|c|c|c|}
\hline Formal Sector & & $\begin{array}{l}\text { DV: Permanent } \\
\text { Contract }\end{array}$ & $\begin{array}{l}\text { DV: Logarithm of } \\
\text { Monthly Wage }\end{array}$ \\
\hline The logarithm of & & $-0.0531 * *$ & -0.0257 \\
\hline $\begin{array}{l}\text { Syrian Migrant } \\
\text { Population }\end{array}$ & & $(0.0260)$ & $(0.0213)$ \\
\hline No. Observations & & 332 & 538 \\
\hline Centered R-square & & 0.2316 & 0.2595 \\
\hline \multicolumn{4}{|l|}{ Informal Sector } \\
\hline The logarithm of & & $-0.0263^{* *}$ & $-0.0300 *$ \\
\hline $\begin{array}{l}\text { Syrian Migrant } \\
\text { Population }\end{array}$ & & (0.0119) & $(0.0158)$ \\
\hline No. Observations & & 655 & 325 \\
\hline Centered R-square & & 0.5011 & 0.1721 \\
\hline High Skill & $\begin{array}{l}\text { DV: Formal } \\
\text { Employment }\end{array}$ & $\begin{array}{l}\text { DV: Permanent } \\
\text { Contract }\end{array}$ & $\begin{array}{l}\text { DV: Logarithm of } \\
\text { Monthly Wage }\end{array}$ \\
\hline $\begin{array}{c}\text { The logarithm of } \\
\text { Syrian Migrant } \\
\text { Population }\end{array}$ & $\begin{array}{c}0.0252^{* * *} \\
(0.0050)\end{array}$ & $\begin{array}{c}0.0014 \\
(0.0013)\end{array}$ & $\begin{array}{l}-0.0317 \\
(0.0450)\end{array}$ \\
\hline No. Observations & 196 & 196 & 141 \\
\hline Centered R-square & 0.9430 & 0.6613 & 0.5237 \\
\hline \multicolumn{4}{|l|}{ Low Skill } \\
\hline Logarithm of Syrian & $0.0175^{* * *}$ & $-0.0232 * *$ & $-0.0132 *$ \\
\hline Migrant Population & $(0.0054)$ & $(0.0108)$ & $(0.0071)$ \\
\hline No. Observations & 791 & 791 & 722 \\
\hline Centered R-square & 0.8631 & 0.4782 & 0.4782 \\
\hline
\end{tabular}

Wild Bootstrap Combined with Regional-Level Clustered Standard Errors in Parenthesis, P-values within brackets, ***, ** and * denote significance at $1 \%, 5 \%$ and $10 \%$ level. 


\section{APPENDIX B: Additional Estimates for Turkey}

In tables B1-B2, we report the results for the DID-IV GMM estimators for the natives and migrants, respectively, in Turkey across the demographic and socio-economic groups we presented in the previous tables for Jordan. The results are heterogeneous, as we find a positive impact on employment opportunities in the formal sector under permanent positions for males but women are more likely to be employed in temporary positions. Furthermore, the effect on labour force participation and annual wages is higher in the sample of males. A similar conclusion is derived from the analysis across education groups, where high educated individuals are more likely to be employed in permanent positions in the formal sector, while low educated respondents are negatively influenced by the Syrian refugee crisis in terms of job security and formal employment. Both high and low-skilled natives, as well as both high and low-educated workers, experience an increase in their annual wages, where the impact is almost doubled for the high-skilled and high-educated workers. Overall, even though the Syrian refugees have a positive impact on natives' labour outcomes in Turkey, based on the results of table B1, women, young and low educated are negatively affected by the refugee crisis, as respondents belonging to these groups are more likely to be unemployed or employed under temporary contracts.

The results in table B2 confirm the negative impact of the Syrian refugees on the labour outcomes of migrants in Turkey. The effect is higher for females, low educated, and young, indicating the substantial discrepancies across those groups. The effect is higher for females, low educated, and young, indicating the substantial discrepancies across those groups. Furthermore, we found a negative impact on formal employment, and those aged 36-64 are more likely to have social security but an insignificant influence on the permanent contract, unemployment, labour force participation and wages for highly educated individuals. Moreover, migrants employed in the informal sector are more likely to work under temporary contracts. When we decompose our analysis by high and low-skilled migrants, we find a significant and positive impact on formal employment, due to the refugee crisis, only for the highskilled workers, but we find a negative probability for being employed under a permanent contract for the low-skilled workers. Regarding wages, the refugee crisis has a negative and significant impact on low and high-skilled migrants, with the former group experiencing a higher fall. However, the effect is negligible, where a 1 percent increase in the Syrian refugee population is associated with a decline of wages ranging around 0.05 and 0.09 percentage points. 
Table B1: DID-IV Estimates for Natives in Turkey Across Groups

\begin{tabular}{|c|c|c|c|c|c|}
\hline Male & $\begin{array}{l}\text { DV: Formal } \\
\text { Employment }\end{array}$ & $\begin{array}{c}\text { DV: } \\
\text { Unemployment }\end{array}$ & $\begin{array}{c}\text { DV: Permanent } \\
\text { Contract }\end{array}$ & $\begin{array}{l}\text { DV: Labour Force } \\
\text { Participation }\end{array}$ & $\begin{array}{l}\text { DV: Logarithm of } \\
\text { Annual Wage }\end{array}$ \\
\hline The logarithm of Syrian & $0.0154 * * *$ & $-0.0068 * * *$ & $0.0038 * * *$ & $0.0191 * * *$ & $0.0122 * * *$ \\
\hline Migrant Population & $(0.0019)$ & $(0.0021)$ & $(0.0011)$ & $(0.0035)$ & $(0.0016)$ \\
\hline No. Observations & 153,868 & 197,523 & 118,208 & 159,546 & 110,929 \\
\hline Centered R-square & 0.2435 & 0.344 & 0.0116 & 0.0097 & 0.0776 \\
\hline \multicolumn{6}{|l|}{ Female } \\
\hline The logarithm of Syrian & 0.0016 & 0.0089 & $-0.0025^{* * *}$ & $0.0123^{* * *}$ & $0.0087^{* * *}$ \\
\hline Migrant Population & $(0.0013)$ & (0.0118) & $(0.0007)$ & $(0.0021)$ & $(0.0005)$ \\
\hline No. Observations & 48,305 & 55,089 & 44,513 & 172,840 & 41,294 \\
\hline Centered R-square & 0.6112 & 0.0245 & 0.0298 & 0.0370 & 0.0379 \\
\hline High Education & $\begin{array}{l}\text { DV: Formal } \\
\text { Employment }\end{array}$ & $\begin{array}{c}\text { DV: } \\
\text { Unemployment }\end{array}$ & $\begin{array}{c}\text { DV: Permanent } \\
\text { Contract }\end{array}$ & $\begin{array}{l}\text { DV: Labour Force } \\
\text { Participation }\end{array}$ & $\begin{array}{l}\text { DV: Logarithm of } \\
\text { Annual Wage }\end{array}$ \\
\hline The logarithm of Syrian & $0.0158^{* * *}$ & $-0.0232 * * *$ & $0.0187^{* * *}$ & $0.0213 * * *$ & $0.0155^{* * *}$ \\
\hline Migrant Population & $(0.0010)$ & $(0.0089)$ & $(0.0020)$ & (0.0089) & $(0.0021)$ \\
\hline No. Observations & 57,163 & 65,693 & 49,419 & 75,908 & 46,513 \\
\hline Centered R-square & 0.0150 & 0.0165 & 0.0158 & 0.0153 & 0.0532 \\
\hline \multicolumn{6}{|l|}{ Low Education } \\
\hline The logarithm of Syrian & $-0.0013^{* * *}$ & $-0.0053 * * *$ & $-0.0048 * * *$ & $0.0089 * * *$ & $0.0075^{* * *}$ \\
\hline Migrant Population & $(0.0001)$ & $(0.0004)$ & $(0.0011)$ & $(0.0022)$ & $(0.0018)$ \\
\hline No. Observations & 145,010 & 186,919 & 113,302 & 256,478 & 105,710 \\
\hline Centered R-square & 0.0146 & 0.0080 & 0.0152 & 0.3001 & 0.0151 \\
\hline Age 16-35 & $\begin{array}{l}\text { DV: Formal } \\
\text { Employment }\end{array}$ & $\begin{array}{c}\text { DV: } \\
\text { Unemployment }\end{array}$ & $\begin{array}{c}\text { DV: Permanent } \\
\text { Contract }\end{array}$ & $\begin{array}{l}\text { DV: Labour Force } \\
\text { Participation }\end{array}$ & $\begin{array}{l}\text { DV: Logarithm of } \\
\text { Annual Wage }\end{array}$ \\
\hline The logarithm of Syrian & $0.0064^{* * *}$ & $0.0035^{* *}$ & $-0.0027^{*}$ & $0.0116^{* * *}$ & $0.0059 * * *$ \\
\hline Migrant Population & $(0.0012)$ & $(0.0014)$ & $(0.0014)$ & (0.0007) & $(0.0014)$ \\
\hline No. Observations & 105,640 & 184,611 & 87,273 & 181,698 & 83,197 \\
\hline Centered R-square & 0.0188 & 0.0138 & 0.0185 & 0.0117 & 0.0761 \\
\hline \multicolumn{6}{|l|}{ Age 36-64 } \\
\hline The logarithm of Syrian & $0.0121 * * *$ & $-0.0062 * * *$ & $0.0115^{* * *}$ & $0.0158^{* * *}$ & $0.0061 * * *$ \\
\hline Migrant Population & $(0.0014)$ & $(0.005)$ & $(0.0015)$ & $(0.0008)$ & $(0.0022)$ \\
\hline No. Observations & 96,533 & 68,001 & 75,448 & 150,688 & 69,026 \\
\hline Centered R-square & 0.0143 & 0.0210 & 0.4130 & 0.0211 & 0.0526 \\
\hline
\end{tabular}




\begin{tabular}{|c|c|c|c|c|}
\hline Formal Sector & & & $\begin{array}{l}\text { DV: Permanent } \\
\text { Contract }\end{array}$ & $\begin{array}{l}\text { DV: Logarithm of } \\
\text { Annual Wage }\end{array}$ \\
\hline The logarithm of Syrian & & & $0.0206 * * *$ & $0.0136^{* * *}$ \\
\hline Migrant Population & & & $(0.0023)$ & $(0.0016)$ \\
\hline No. Observations & & & 105,480 & 101,792 \\
\hline Centered R-square & & & 0.0148 & 0.0501 \\
\hline \multicolumn{5}{|l|}{ Informal Sector } \\
\hline The logarithm of Syrian & & & $0.0038^{* * *}$ & $0.0084^{* * *}$ \\
\hline Migrant Population & & & (0.0009) & $(0.0032)$ \\
\hline No. Observations & & & 57,241 & 50,431 \\
\hline Centered R-square & & & 0.0084 & 0.0719 \\
\hline High Skill & $\begin{array}{l}\text { DV: Formal } \\
\text { Employment }\end{array}$ & & $\begin{array}{l}\text { DV: Permanent } \\
\text { Contract }\end{array}$ & $\begin{array}{l}\text { DV: Logarithm of } \\
\text { Annual Wage }\end{array}$ \\
\hline Logarithm of Syrian Migrant & $0.0217^{* * *}$ & & $0.0493^{* * *}$ & $0.0333^{* * *}$ \\
\hline Population & $(0.0010)$ & & $(0.0021)$ & $(0.0031)$ \\
\hline No. Observations & 93,141 & & 73,604 & 69,609 \\
\hline Centered R-square & 0.2034 & & 0.2892 & 0.3028 \\
\hline \multicolumn{5}{|l|}{ Low Skill } \\
\hline Logarithm of Syrian Migrant & $-0.0089 * * *$ & 0.0218 & $0.0067^{* * *}$ & $0.0172^{* * *}$ \\
\hline Population & $(0.0012)$ & $(0.0220)$ & $(0.0008)$ & $(0.0015)$ \\
\hline No. Observations & 109,032 & 130 & 89,117 & 82,614 \\
\hline Centered R-square & 0.2713 & 0.6837 & 0.1130 & 0.5798 \\
\hline
\end{tabular}

Wild Bootstrap Combined with Regional-Level Clustered Standard Errors in Parenthesis, P-values within brackets, ***, ** and * denote significance at $1 \%, 5 \%$ and $10 \%$ level. 
Table B2: DID-IV Estimates for Migrants in Turkey Across Groups

\begin{tabular}{|c|c|c|c|c|c|}
\hline Male & $\begin{array}{l}\text { DV: Formal } \\
\text { Employment }\end{array}$ & $\begin{array}{c}\text { DV: } \\
\text { Unemployment }\end{array}$ & $\begin{array}{c}\text { DV: Permanent } \\
\text { Contract }\end{array}$ & $\begin{array}{l}\text { DV: Labour Force } \\
\text { Participation }\end{array}$ & $\begin{array}{c}\text { DV: Logarithm of } \\
\text { Annual Wage }\end{array}$ \\
\hline The logarithm of & $-0.0572 * *$ & -0.0018 & $-0.0396 *$ & $0.0189 * *$ & -0.0450 \\
\hline $\begin{array}{l}\text { Syrian Migrant } \\
\text { Population }\end{array}$ & $(0.0278)$ & $(0.0027)$ & $(0.0203)$ & $(0.0085)$ & $(0.0458)$ \\
\hline No. Observations & 411 & 571 & 391 & 563 & 356 \\
\hline Centered R-square & 0.2017 & 0.0310 & 0.0666 & 0.0236 & 0.1183 \\
\hline \multicolumn{6}{|l|}{ Female } \\
\hline $\begin{array}{c}\text { The logarithm of } \\
\text { Syrian Migrant } \\
\text { Population }\end{array}$ & $\begin{array}{c}-0.1001^{* *} \\
(0.0442)\end{array}$ & $\begin{array}{c}0.0040 \\
(0.0026)\end{array}$ & $\begin{array}{c}-0.0567^{* *} \\
(0.0236)\end{array}$ & $\begin{array}{c}-0.0758 * * * \\
(0.0237)\end{array}$ & $\begin{array}{c}-0.2711^{* * *} \\
(0.0833)\end{array}$ \\
\hline No. Observations & 131 & 225 & 113 & 459 & 128 \\
\hline Centered R-square & 0.1468 & 0.1470 & 0.1335 & 0.0231 & 0.1606 \\
\hline High Education & $\begin{array}{l}\text { DV: Formal } \\
\text { Employment }\end{array}$ & $\begin{array}{c}\text { DV: } \\
\text { Unemployment }\end{array}$ & $\begin{array}{c}\text { DV: Permanent } \\
\text { Contract }\end{array}$ & $\begin{array}{l}\text { DV: Labour Force } \\
\text { Participation }\end{array}$ & $\begin{array}{c}\text { DV: Logarithm of } \\
\text { Annual Wage }\end{array}$ \\
\hline $\begin{array}{l}\text { The logarithm of } \\
\text { Syrian Migrant } \\
\text { Population }\end{array}$ & $\begin{array}{c}-0.0386^{* *} \\
(0.0182)\end{array}$ & $\begin{array}{l}-0.0178 \\
(0.0159)\end{array}$ & $\begin{array}{l}-0.0034 \\
(0.0094)\end{array}$ & $\begin{array}{l}-0.0187 \\
(0.0163)\end{array}$ & $\begin{array}{c}0.0621 \\
(0.0588)\end{array}$ \\
\hline No. Observations & 138 & 181 & 111 & 277 & 102 \\
\hline Centered R-square & 0.1245 & 0.0219 & 0.0441 & 0.0247 & 0.0998 \\
\hline \multicolumn{6}{|l|}{ Low Education } \\
\hline $\begin{array}{c}\text { The logarithm of } \\
\text { Syrian Migrant } \\
\text { Population }\end{array}$ & $\begin{array}{c}-0.0881^{* *} \\
(0.0396)\end{array}$ & $\begin{array}{l}0.0033^{*} \\
(0.0019)\end{array}$ & $\begin{array}{c}-0.0831 * * \\
(0.0387)\end{array}$ & $\begin{array}{c}-0.0314 * * \\
(0.0151)\end{array}$ & $\begin{array}{c}-0.1144^{* *} \\
(0.0462)\end{array}$ \\
\hline No. Observations & 404 & 615 & 393 & 745 & 382 \\
\hline Centered R-square & 0.0597 & 0.0277 & 0.2005 & 0.0324 & 0.0658 \\
\hline Age 16-35 & $\begin{array}{l}\text { DV: Formal } \\
\text { Employment }\end{array}$ & $\begin{array}{c}\text { DV: } \\
\text { Unemployment }\end{array}$ & $\begin{array}{c}\text { DV: Permanent } \\
\text { Contract }\end{array}$ & $\begin{array}{l}\text { DV: Labour Force } \\
\text { Participation }\end{array}$ & $\begin{array}{c}\text { DV: Logarithm of } \\
\text { Annual Wage }\end{array}$ \\
\hline $\begin{array}{c}\text { The logarithm of } \\
\text { Syrian Migrant } \\
\text { Population }\end{array}$ & $\begin{array}{c}-0.0894 * * \\
(0.0425)\end{array}$ & $\begin{array}{c}0.0061 \\
(0.0166)\end{array}$ & $\begin{array}{c}-0.0642^{* *} \\
(0.0318)\end{array}$ & $\begin{array}{l}-0.0044 \\
(0.0170)\end{array}$ & $\begin{array}{c}-0.1415^{* *} \\
(0.0574)\end{array}$ \\
\hline No. Observations & 218 & 422 & 198 & 553 & 183 \\
\hline Centered R-square & 0.0380 & 0.0107 & 0.1129 & 0.2361 & 0.1254 \\
\hline \multicolumn{6}{|l|}{ Age 36-64 } \\
\hline $\begin{array}{c}\text { The logarithm of } \\
\text { Syrian Migrant } \\
\text { Population }\end{array}$ & $\begin{array}{l}0.0395^{*} \\
(0.0202)\end{array}$ & $\begin{array}{c}-0.0179 * * \\
(0.0084)\end{array}$ & $\begin{array}{l}-0.0267 * \\
(0.0142)\end{array}$ & $\begin{array}{l}-0.0330 * \\
(0.0179)\end{array}$ & $\begin{array}{l}-0.0430 \\
(0.0604)\end{array}$ \\
\hline No. Observations & 324 & 374 & 306 & 469 & 301 \\
\hline Centered R-square & 0.2132 & 0.0371 & 0.0424 & 0.0267 & 0.2298 \\
\hline
\end{tabular}




\begin{tabular}{|c|c|c|c|}
\hline Formal Sector & & $\begin{array}{l}\text { DV: Permanent } \\
\text { Contract }\end{array}$ & $\begin{array}{l}\text { DV: Logarithm of } \\
\text { Annual Wage }\end{array}$ \\
\hline The logarithm of & & 0.0038 & -0.0710 \\
\hline $\begin{array}{l}\text { Syrian Migrant } \\
\text { Population }\end{array}$ & & $(0.0043)$ & $(0.0501)$ \\
\hline No. Observations & & 286 & 275 \\
\hline Centered R-square & & 0.0797 & 0.0762 \\
\hline \multicolumn{4}{|l|}{ Informal Sector } \\
\hline The logarithm of & & $-0.0718^{* *}$ & 0.0472 \\
\hline $\begin{array}{l}\text { Syrian Migrant } \\
\text { Population }\end{array}$ & & $(0.0309)$ & $(0.0508)$ \\
\hline No. Observations & & 218 & 209 \\
\hline Centered R-square & & 0.1751 & 0.0523 \\
\hline High Skill & $\begin{array}{l}\text { DV: Formal } \\
\text { Employment }\end{array}$ & $\begin{array}{l}\text { DV: Permanent } \\
\text { Contract }\end{array}$ & $\begin{array}{l}\text { DV: Logarithm of } \\
\text { Annual Wage }\end{array}$ \\
\hline $\begin{array}{l}\text { The logarithm of } \\
\text { Syrian Migrant } \\
\text { Population }\end{array}$ & $\begin{array}{l}0.1354^{*} \\
(0.0717)\end{array}$ & $\begin{array}{c}0.0215 \\
(0.0323)\end{array}$ & $\begin{array}{c}-0.0539 * * \\
(0.0243)\end{array}$ \\
\hline No. Observations & 174 & 166 & 159 \\
\hline Centered R-square & 0.4296 & 0.8410 & 0.8410 \\
\hline \multicolumn{4}{|l|}{ Low Skill } \\
\hline Logarithm of Syrian & 0.0218 & $-0.0578^{* *}$ & $-0.0913 * *$ \\
\hline Migrant Population & $(0.0220)$ & $(0.0257)$ & $(0.0410)$ \\
\hline No. Observations & 368 & 338 & 325 \\
\hline Centered R-square & 0.6837 & 0.1751 & 0.6741 \\
\hline
\end{tabular}

Wild Bootstrap Combined with Regional-Level Clustered Standard Errors in Parenthesis, P-values within brackets, $*^{* *},{ }^{* *}$ and * denote significance at $1 \%, 5 \%$ and $10 \%$ level. 